UNITED STATES

DEPARTMENT OF THE INTERIOR

GEOLOGICAL SURVEY

FLOODS FROM DAM FAILURES

By John E. Costa

Open-File Report 85-560

Denver, Colorado

1985 


\section{UNITED STATES DEPARTMENT OF THE INTERIOR}

DONALD PAUL HODEL, SECRETARY

GEOLOGICAL SURVEY

Dallas L. Peck, Director

For additional information write to:

John E. Costa

U.S. Geological Survey

Water Resources Division

Box 25046, MS 413, DFC

Denver, C0 80225
Copies of this report can be purchased from:

Open-File Services Section Western Distribution Branch Box 25425, Federal Center Denver, Colorado 80225

(Telephone: (303) 236-7476) 
CONVERSION FACTORS

International System (SI) units in this report may be converted to inchpound units by the following conversion factors:

Divide SI units

cubic meter per second $\left(\mathrm{m}^{3} / \mathrm{s}\right)$

meter (m)

meter per minute (m/minute)

cubic meter $\left(\mathrm{m}^{3}\right)$

kilometer $(\mathrm{km})$

square kilometer $\left(\mathrm{km}^{2}\right)$

metric tonne
By

0.02832

0.3048

0.3048

1233

1.609

2.590

0.9072

To convert degrees Celsius $\left({ }^{\circ} \mathrm{F}\right)$, use the following equation:

$$
{ }^{O} F=9 / 5\left({ }^{\circ} \mathrm{C}+32\right) .
$$




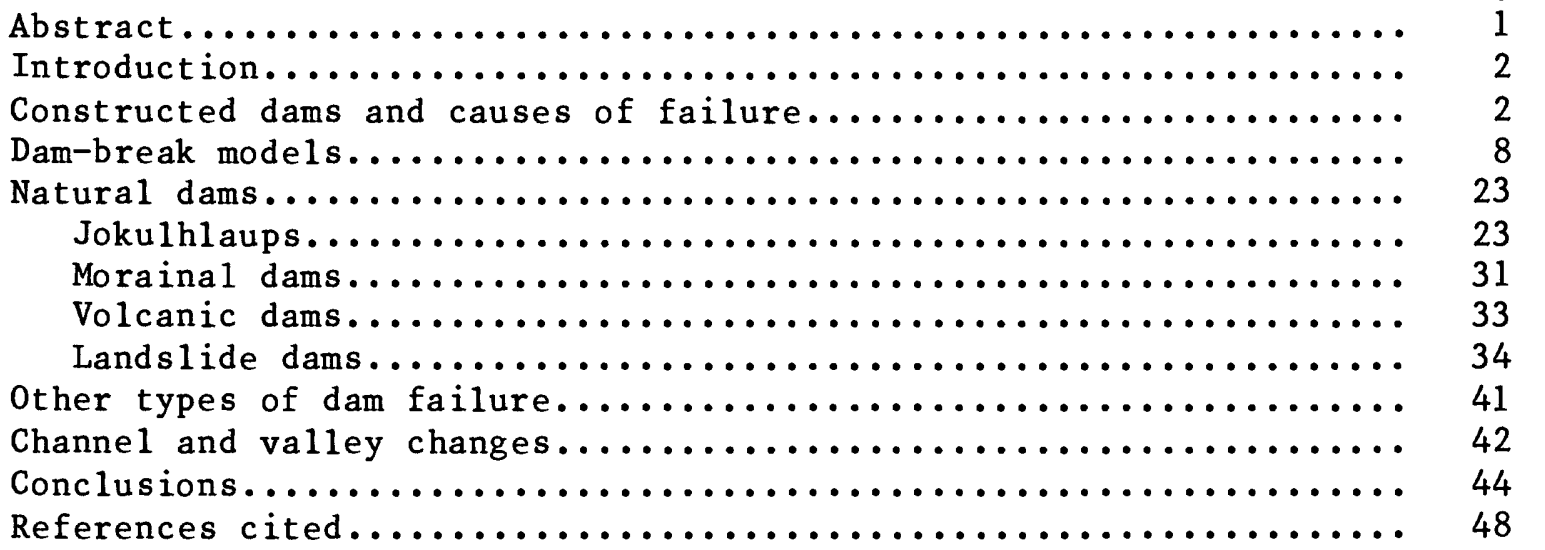

\section{ILLUSTRATIONS}

Figure 1. Graphs showing causes of failure for different dam types more than 15 meters high (International Commission on Large Dams, 1973 )......................

2. Graphs showing age of dams at time of failure, for different dam types more than 15 meters high

(International Commission on Large Dams, 1973).........

3. Graphs showing types of dams built in Western Europe and the United States, and their failure percentage, between 1900-69 (International Commission on Large

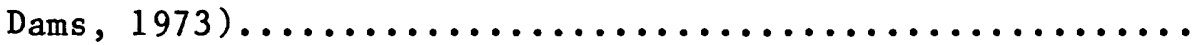

4. Graph showing dam height ( $\mathrm{H}$, in meters) versus peak discharge $\left(Q_{\max }\right.$ in cubic meters per second) for constructed, glacial, and landslide dams with numbers

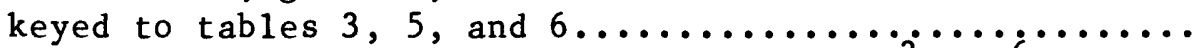

5. Graph showing reservoir volume ( $\mathrm{V}$, in $\left.\mathrm{m}^{3} \mathrm{x} 10^{6}\right)$ versus peak discharge $\left(Q_{\max }\right.$ in cubic meters per second) for constructed, glacial, and landslide dams with numbers keyed to tables 3,5 , and $6 \ldots \ldots \ldots \ldots \ldots \ldots$ Photographs showing sequence of Cascade Lake Dam failure, Colorado, July 15, 1982 (from Jarrett

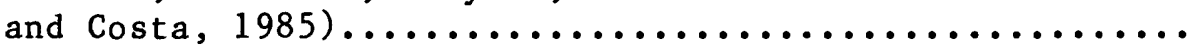

- Graph showing dam-factor ( $\mathrm{H} \times \mathrm{V}$ ) versus peak discharge $\left(Q_{\max }\right)$ for 29 dam failures with numbers keyed to

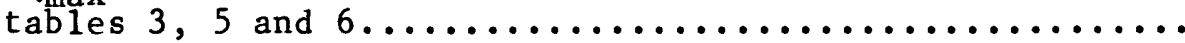

8. Graph showing attenuation rates of floods from selected dam failures, with numbers keyed to table 4....

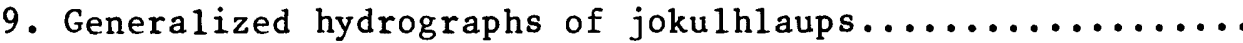

10. A. Aerial photograph of Nostetuko Lake and Cumberland Glacier, British Columbia, Canada, in July, 1977. (Photo by J. M. Ryder, courtesy of Michael Church)....... 
B. Aerial photograph of Nostetuko Lake and Cumberland Glacier, British Columbia, Canada, in August, 1983, after the morainal dam was breached.

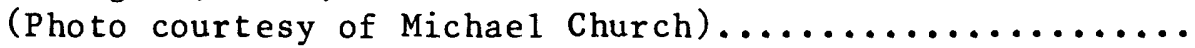

11. Photograph of Castle Lake, Mount St. Helens, Washington, dammed by a debris avalanche deposit. Debris avalanche moved from left to right in photo. An artificial spillway was cut into the right embankment. (April, 1984)

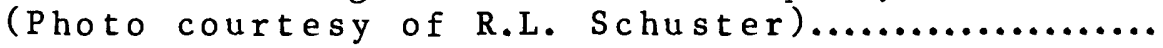

12. Cross-section of Mayunmarca landslide dam, Peru, compared to the maximum cross-section of a large earth-fill dam at Oroville, California. (from Lee and Duncan, 1975$) \ldots \ldots \ldots \ldots \ldots \ldots \ldots \ldots \ldots \ldots \ldots . . \ldots \ldots$

13. Hydrograph of discharge resulting from the 1974 failure of Mayunmarca landslide dam, Peru. (from

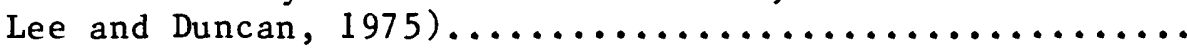

14. Damage from collapse of giant molasses tank at Boston harbor, January 15, 1919. View along

Atlantic Avenue. Photo courtesy of the Boston Public Library, Print Department................ 43

15. Photograph of Teton River valley at Newdale, Idaho showing area of bedrock erosion along the left bank after the Teton Dam failure in 1976. Person in center of photograph for scale.......

TABLES

Table 1. Loss of life and property damage from notable U.S. dam failures, 1963-1983 (Graham, 1983)........... 9-10

2. Comparison of warning success for selected dam failures and flash floods (Graham, 1983).............. 11

3. Constructed dams that have failed.................. 14-16

4. Attenuation rates from some historic dam-failure

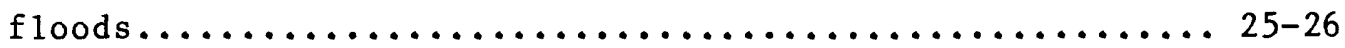

5. Some glacial dams that have failed, producing jokulhlaups.............................. 29-30

6. Summary of some landslide dams that have failed................................. 38

7. Summary of regression equations to predict peak discharge for constructed, landslide, and glacial dams.............................. 


\title{
FLOODS FROM DAM FAILURES
}

\author{
by John E. Costa
}

\section{ABSTRACT}

Floods resulting from dam failures usually are much larger than those originating from snowmelt or rainfall. Dams can be classified as constructed dams and natural dams. Constructed dams are usually concrete arch, buttress, or gravity dams, and earth- or rock-fill dams. Natural dams include ice dams, morainal dams, volcanic dams, and landslide dams. other unusual kinds of dam failures include drainage of lakes by underground mining, bursts of large water-diversion pipes, bursts of water stored in peatlands (bog-bursts), and failures of large-volume industrial containers.

During the last 100 years, there have been about 200 significant failures of constructed dams, resulting in the death of more than 11,100 people. More than 60 percent of this loss of 1 ife occurred in three failures alone: Vaiont, Italy, 1963 (2,600), South Fork (Johnstown) Pennsylvania, U.S.A., $1889(2,200)$, and Machhu II, India, $1974(2,000+)$. Major causes of constructed-dam failures are overtopping due to an inadequate spillway ( 34 percent), foundation defects ( 30 percent), and piping and seepage ( 28 percent). An order-of-magnitude estimate of risk of dam failure is approximately $10^{-4}$ per dam-year. In the United States for the last 2 decades, the annual loss of 1 ife from dam failures has been about 14. The average number of fatalities per dam failure is 19 times greater when there is inadequate or no warning.

The release of ice-dammed lakes can occur by raising the ice barrier by hydrostatic flotation, or by drainage and subsequent en largement of cracks and tunnels in the ice dam. Flood peaks predicted from failure of glacial dams have the lowest standard error of prediction using the product of dam height and reservoir volume. Flood peaks from failure of ice dams generally are smaller than flood peaks resulting from failure of constructed and landslide dams of the same height or impounding the same volume. However the largest flood known to have occurred on the surface of the Earth, the "Spokane Flood" in eastern Washington, U.S.A., originated from the sudden release of water from Glacial Lake Missoula when an ice dam failed between 16,000 and 12,000 years ago.

Landslide dams are a world-wide phenomenon. They typically are much wider and involve larger volumes of sediment than constructed dams of the same height. Consequent1y when a landslide dam fails, there commonly is much more sediment and debris to erode before a full breach is developed. Thus floods resulting from failure of landslide dams generally have smaller flood peaks than floods from failed constructed dams with the same dam height and reservoir volume. Natural dams of pyroclastic sediments seem to be the most susceptable to rapid failure.

For rapid prediction purposes, when potential loss of life or property is involved, a conservative peak-discharge estimate based on envelope curves developed from historic dam failures can be made from knowledge of 
dam height and reservoir volume. For reconstructing past flood peaks from dam failures for paleohydrological or sedimentological investigations, regression equations with dam height and volume as independent variables produce equations with standard errors of 75 to 147 percent. For all types of dams, the dam factor (height times volume of water), a rough measure of potential energy, produced the lowest average standard error.

After large floods from dam failures, one or more of the following characteristics can be expected: (1) Aggradation of the valley upstream by trapped sediment, (2) triggering of landslides by the rapid draw-down of reservoir water levels, (3) large amounts of local scour and deposition downstream, (4) erosion of bedrock along valley walls, and (5) the formation of wide, shallow, braided channels downstream.

\section{INTRODUCTION}

The purpose of this report is to summarize, in a general way, information about the hydrology and geomorphology of floods produced from the failure of natural and constructed dams. Floods resulting from dam failures usually are much larger than those originating from snowmelt or rainfa11. The sudden release of large quantities of stored water from a breached dam can cause great destruction to property and potential loss of life downstream. The volumes and magnitudes of some floods from dam failures may be unprecedented in the cultural and natural history of the affected valley. Tremendous quantities of sediment and debris eroded, transported, and deposited downstream can cause significant modifications to channels and valley morphology. Floods from dam failures have produced shear stresses and unit stream powers comparable to the largest rainfal1runoff or snowmelt floods ever measured in the United States (J. E. Costa, U.S. Geological Survey, unpub. data, 1985).

Dams generally can be categorized as constructed dams and natural dams. Within each category there are numerous types.

\section{CONSTRUCTED DAMS AND CAUSES OF FAILURES}

The construction of dams to create reservoirs for water supply was one of the earliest engineering undertakings. Remains of one of the oldest constructed dams in the wor $1 \mathrm{~d}$, believed to date from ca. 2900 B.C., still survive in the Wadi el-Garawi about $32 \mathrm{~km}$ south of Cairo, Egypt. This rubble-masonry structure was $107 \mathrm{~m}$ long, $11 \mathrm{~m} \mathrm{high,} \mathrm{and} \mathrm{had} \mathrm{a} \mathrm{reservoir}$ capacity of $570,000 \mathrm{~m}^{3}$ (Jansen, 1980). The Romans built many stone dams throughout their empire, the earliest near Toledo, Spain sometime after 193 B.C. In the United States, the first dams were constructed to impound water to run gristmills and sawmills. One of the earliest dams was erected in 1623 to run the first sawmill in America on the Piscataqua River at South Windham, Maine. On the western coast of the United States, Jesuits constructed one of the earliest dams on the San Diego River in 1770 (Jansen, 1980). 
In the United States, the National Dam Inspection Program (Public Law 92-367) compiled data on about 68,000 dams that were either more than 7.6 $\mathrm{m}$ high, or impounded at least $61,650 \mathrm{~m}^{3}$ at maximum water-storage elevation. Earth- and rockfill dams by far constitute the largest percentage of dam types (93 percent). Their characteristics consist of an impermeable barrier made from compaction of fine-grained materials, combined with a mass of earth and rock material to impound water. An earthfill dam is an embankment dam in which more than 50 percent of the total volume is formed of compacted fine-grained material obtained from a borrow area. A rockfill dam is an embankment dam in which more than 50 percent of the total volume consists of compacted or dumped pervious natural or crushed rock. Foundation requirements are less stringent than for other types of dams.

A gravity dam, constructed of concrete or masonry or both, relies on its weight for stability. Gravity dams represented 5 percent of the investigated dams. An arch dam ( 0.4 percent of the sample) is a concrete or masonry dam that is curved in plan so as to transmit the major proportion of the water stress to the bedrock abutments. Buttress dams ( 0.3 percent of the sample) consist of a watertight upstream face supported at intervals on the downstream side by a series of buttresses.

Of the 8,639 dams inspected by the U.S. Army Corps of Engineers by September, 1981, 1/3 were declared unsafe. The primary defect of 82 percent of the dams was inadequate spillway capacity. The two largest groups of owners of unsafe dams are one or more individuals (27.4 percent), and State, city, or county governments (26.4 percent) (Morrison, 1982). By May 1982, no corrective measures had been initiated at 64 percent of the unsafe dams, principally because of the owners' lack of resources (Committee on the Safety of Existing Dams, 1983).

Ever since the earliest dams were built, there have been dam failures. The history and description of the failure of some famous constructed dams throughout the world can be found in Jansen (1980). There have been approximately 2,000 failures of constructed dams throughout the world since the 12th century (Jansen, 1980), and many thousands more failures of natural dams. During the last 100 years, there have been about 200 significant failures of constructed dams, in which more than 11,100 people died; 6,800 lives were lost in three failures alone: Vaiont, Italy, 1963, $(2,600)$, South Fork (Johnstown) Pennsylvania, U.S.A., $1889(2,200)$, and Machhu II, India, $1974(2,000+)$ (Jansen, 1980). Financial losses associated with dam failures probably are inestimable.

Several investigations have attempted to summarize the causes of major dam failures throughout the world. In 1961 the Spanish publication "Revista de Obras Públicas" presented the results of an investigation of 1,620 major dams (as reported in Gruner, 1963). In the 145 years between 1799 and 1944, 308 dams suffered serious accidents or failures. Of these, 57 percent were fill or embankment dams, 23 percent were gravity dams, 3 percent were arch dams, and the remaining 17 percent were other types.

Reported causes of failure were foundation failure (51 percent) including uneven settlement and earthquakes; inadequate spillways (23 
percent); piping and seepage ( 7 percent), including high pore pressures and embankment slips; and various other causes (19 percent), including improper construction, acts of war, defective materials, and incorrect operation.

In a study of more than 300 dam failures throughout the world, Biswas and Chatterjee (1971) reported that about 35 percent were a result of floods exceeding the spillway capacity, and 25 percent resulted from foundation problems such as seepage, piping, excess pore pressure, inadequate cut-off, fault movement, settlement, or rock slides. The remaining 40 percent of the failures were caused by various problems including improper design or construction, inferior materials, misuse, wave action, and acts of war.

The International Commission on Large Dams compiled a survey of dams more than $15 \mathrm{~m}$ in height that failed between 1900 and 1973 (International Commission on Large Dams, 1973). The three main causes of failure were overtopping (inadequate spillway), foundation defects, and piping (fig. 1). The major cause of failure of concrete dams was foundation failure (53 percent), and the major cause of failure of fill or embankment dams was piping and seepage (38 percent). Piping and seepage failures did not occur with any concrete dam. For all dams built, failures by overtopping due to an inadequate spillway ( 34 percent), foundation defects ( 30 percent) and piping and seepage ( 28 percent) have about the same rate of occurrence (fig. 1). These data clearly indicate that the greatest $r$ isks of a dam failing originate from ignorance of the magnitude and frequency of extreme floods, and uncertainities of the geologic setting.

The incidence of the causes of dam failures as a function of the dam's age at the time of failure is shown in figure 2. Foundation failures occur early in a dam's history, whereas other causes take relatively longer to develop. A very large percentage of all dam failures occurs during initial filling since this is the time when design or construction flaws, or latent site defects, will appear.

The percentage of different kinds of dams built in western Europe and the United States between 1900 and 1969 is shown in figure 3. Fill or embankment dams ( 50 percent) were the most numerous types built, gravity dams were second ( 26 percent). The percentage of failures that occurred for the four different types of dams is summarized in figure 3. Nearly 75 percent of the dams that failed were fill dams. However data in figure 3 also show the failed dams as a percentage of the dams built, and indicates that gravity dams were the safest, followed by arch and fill dams. Buttress dams have the poorest safety record; however, they were the least used.

The risk of dam failures in the United States is approximately $3 \mathrm{x}$ $10^{-4}$ to $7 \times 10^{-4}$ per dam-year (Baecher and others, 1980). Worldwide dam failure rates are estimated to be $2 \times 10^{-4}$ to $4 \times 10^{-4}$ per dam-year (Baecher and others, 1980). The seemingly higher dam failure rate in the United States probably is an artifact of better and more comprehensive data on failures than exists in most of the rest of the world. When major dam failures are considered, the United States failure rate is $0.8 \times 10^{-4}$ per 


\section{CONCRETE DAMS}

Overtopping

Foundation defects

Piping and seepage

Others

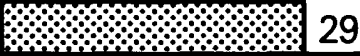

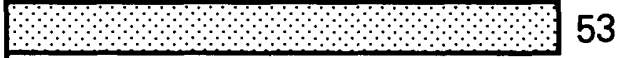

0

:::1::::::::: 18

\section{FILL DAMS}

Overtopping

Foundation defects

Piping and seepage

Others
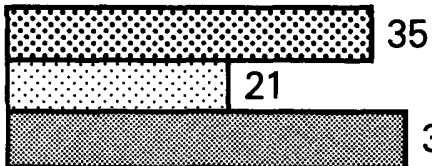

38

::: 6

\section{ALL TYPES OF DAMS}

Overtopping

Foundation defects

Piping and seepage

Others

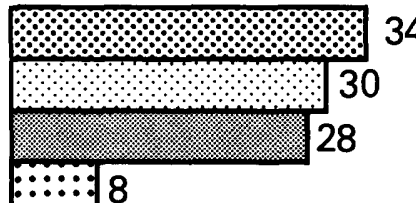

\section{4}

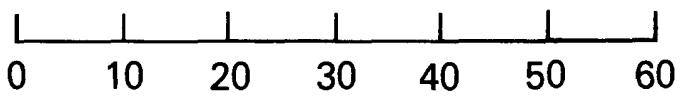

PERCENTAGE OF FAILURES

Figure 1. Graphs showing causes of failure for different dam types more than 15 meters high (International Commission on Large Dams, 1973 ). 


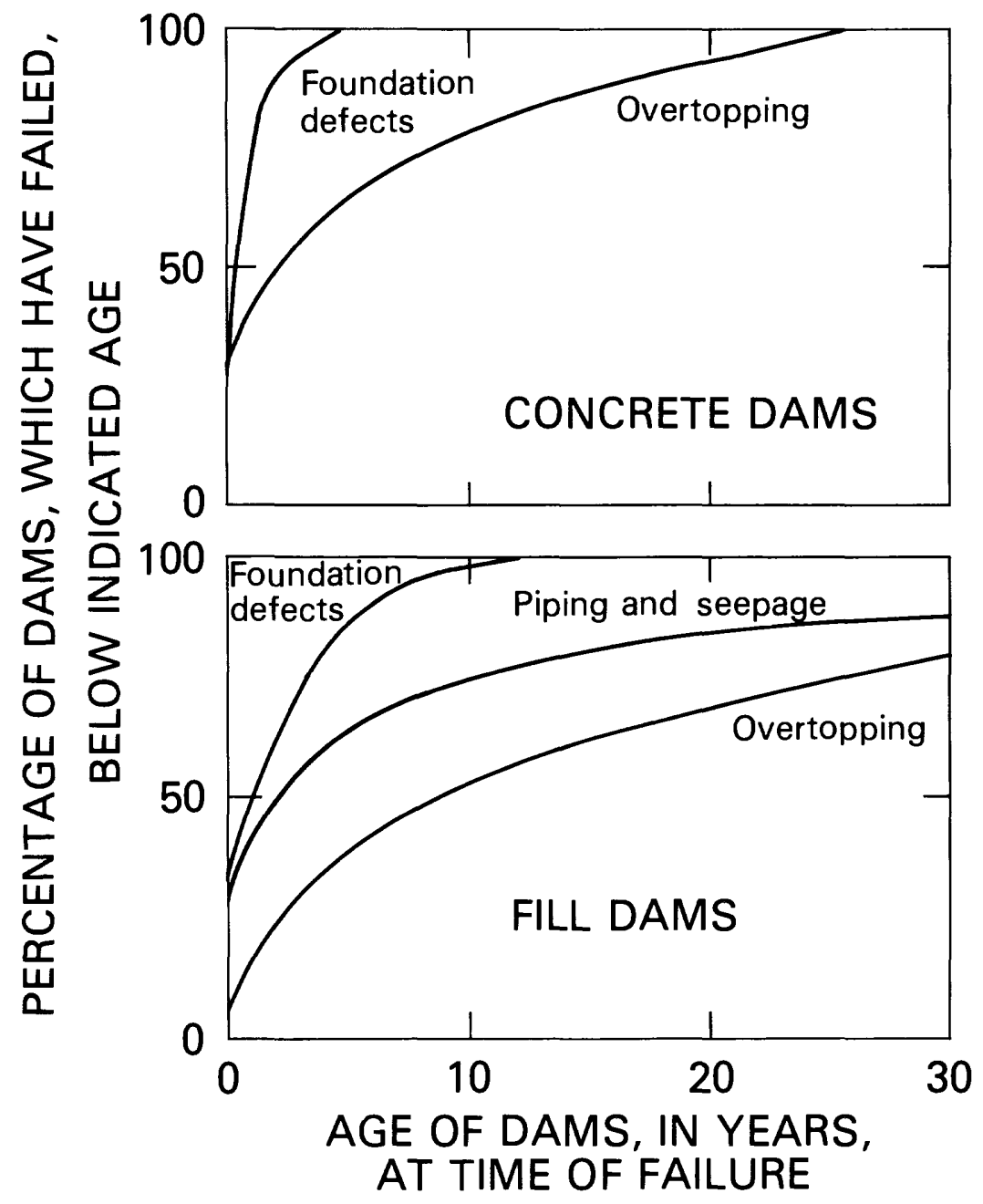

Figure 2. Graphs showing age of dams at time of failure, for different dam types more than 15 meters high (International Commission on Large Dams, 1973). 

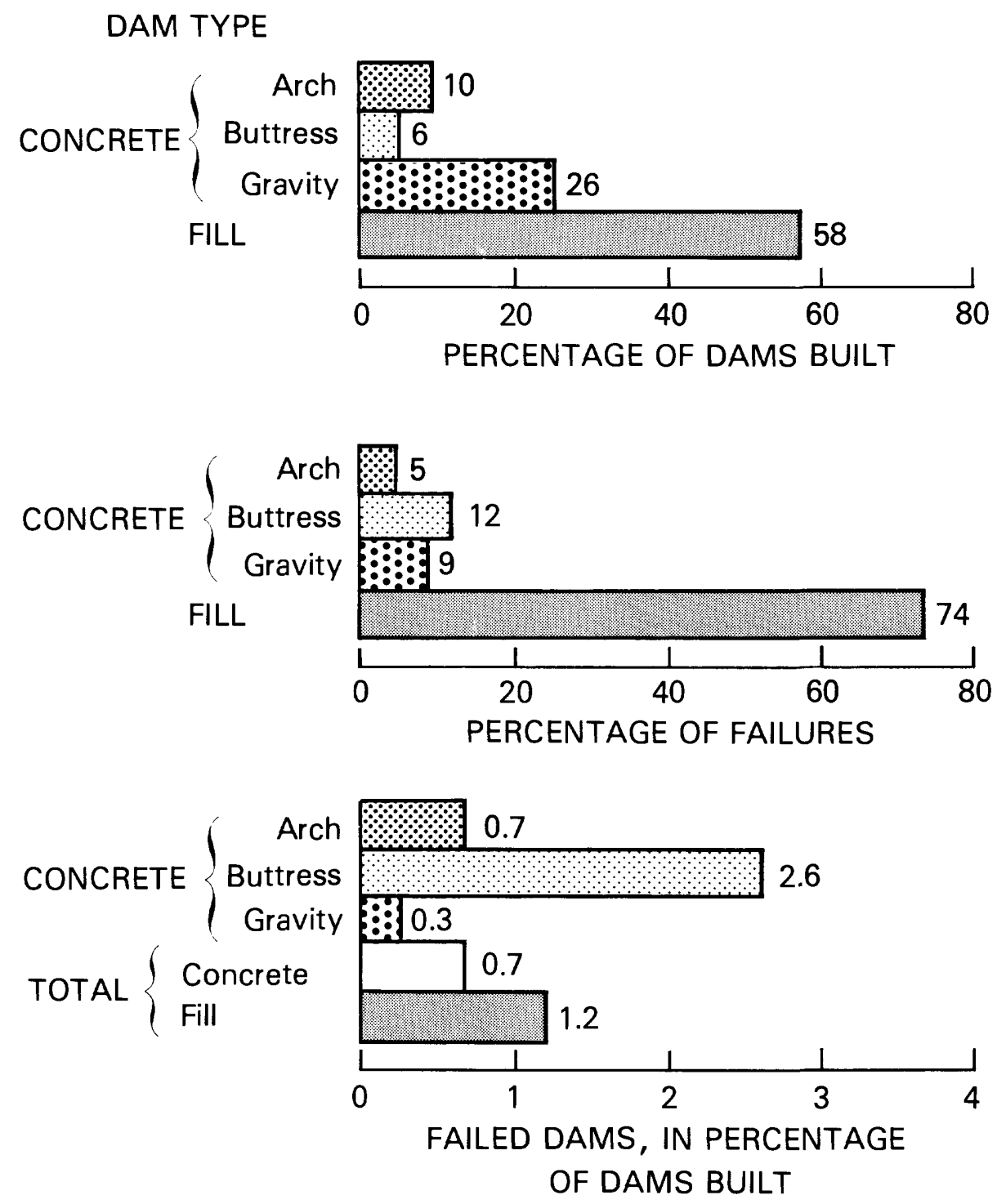

Figure 3. Graphs showing types of dams built in Western Europe and the United States, and their failure percentage, between 1900-69 (International Commission on Large Dams, 1973). 
dam-year, and the world failure rate $2 \times 10^{-4}$ per dam-year (Mark and Stuart-Alexander, 1977). There are many uncertainties in these $k$ inds of estimates, and the only consistent conclusion available is that an orderof-magnitude estimate of risk of dam failure anywhere in the world is approximately $10^{-4}$ per dam-year. This failure rate has been shown to be a significant factor in the cost-benefit analysis of large dams where there is potential for large loss of 1 ife (Mark and Stuart-Alexander, 1977; Rose, 1978).

In the United States between 1963 and 1983, the average annual loss of life from dam failures was about 14 deaths (table 1). This figure compares with 200 deaths per year from flooding, 25 deaths from mass movements, 12 deaths from earthquakes, and 6 deaths from tsunamis (Costa and Baker, 1981, p. 462). Interestingly, the failure of constructed dams less than $15 \mathrm{~m}$ in height caused about 90 percent of all dam-failure fatalities during this period. On the basis of a sample of 20 dams that failed in the United States during this century, Wayne Graham (U.S. Bureau of Reclamation, written commun., 1984) found that the average number of fatalities per dam failure was 19 times greater when there was inadequate or no warning, than when there was adequate warning. The effects of successful warning for some recent dam failures, and the Big Thompson River, Colorado flash flood of 1976, are given in table 2. The data show that in the absence of early detection and warning, a significant percentage of the people exposed to the flood hazard can lose their lives. For example, the failure of the relatively low Laurel Run Dam in Pennsylvania (12.8 $\mathrm{m}$ high) at 4:00 a.m. claimed the lives of about 1 out of every 4 people potentially exposed to floodwaters, because there was no warning. The failure of the 93-m high Teton Dam, Idaho, at 11:57 a.m. was preceded by a warning, and only about 1 out of every 3,000 people potentially exposed to the floodwaters died.

Obviously, there is great benefit to be derived from early warning of the failure of a dam. Some relatively inexpensive actions that communities downstream from hazardous dams could undertake include development of emergency action plans, establishment of an early-warning and notification system, preparation of evacuation plans, stockpiling repair materials, locating local repair forces, training operation personnel, and increasing inspection frequency. However, risk can never be completely eliminated. In 1969, a 76-year-old earth dam near Wheatland, Wyoming, failed without warning, flooding more than $40 \mathrm{~km}^{2}$ of cropland. The failure occurred in dry weather less than 10 hours after the dam had been inspected and found safe (Anonymous, 1969).

\section{DAM-BREAK MODELS}

Many types of dam-break models exist, ranging from simple computations based on historical dam-failure data that can be performed manually, to complex models that require computer analyses. The purpose of each model is to predict the characteristics (such as peak discharge or stage, volume, and flood-wave travel time) of a dam-failure flood. 


\begin{tabular}{|c|c|c|c|c|}
\hline $\begin{array}{c}\text { Name and location } \\
\text { of dam }\end{array}$ & Date & $\begin{array}{l}\text { ef } \\
\text { lure }\end{array}$ & $\begin{array}{l}\text { Number of } \\
\text { lives } 108 \mathrm{t}\end{array}$ & Damages \\
\hline Mohegan Park, Conn. & Mar & 1963 & 6 & $\begin{array}{l}\$ 3 \text { million } \\
(1963 \text { do11ars })\end{array}$ \\
\hline Little Deer Creek, Utah & June & 1963 & 1 & $\begin{array}{l}\text { Many summer cabins } \\
\text { damaged. }\end{array}$ \\
\hline Baldwin Hills, Calif. & Dec & 1963 & 5 & $\begin{array}{l}41 \text { houses destroyed, } \\
986 \text { houses damaged, } \\
100 \text { apartment } \\
\text { buildings damaged. }\end{array}$ \\
\hline Swift, Mont. & June & 1964 & 19 & Unknown. \\
\hline Lower Two Medicine, Mont. & June & 1964 & 9 & Unknown. \\
\hline Lee Lake, Mass. & Mar & 1968 & 2 & $\begin{array}{l}6 \text { houses destroyed, } \\
20 \text { houses damaged, } \\
1 \text { manufacturing plant } \\
\text { damaged or destroyed. }\end{array}$ \\
\hline Buffalo Creek, West Va. & Feb & 1972 & 125 & $\begin{array}{l}546 \text { houses destroyed, } \\
538 \text { houses damaged. }\end{array}$ \\
\hline Lake "O" Hills, Ark. & Apr & 1972 & 1 & Unknown. \\
\hline Canyon Lake, South Dak. & June & 1972 & $33 *$ & $\begin{array}{l}\text { Unable to separate damage } \\
\text { due to failure from } \\
\text { damage caused by natural } \\
\text { flooding. }\end{array}$ \\
\hline
\end{tabular}




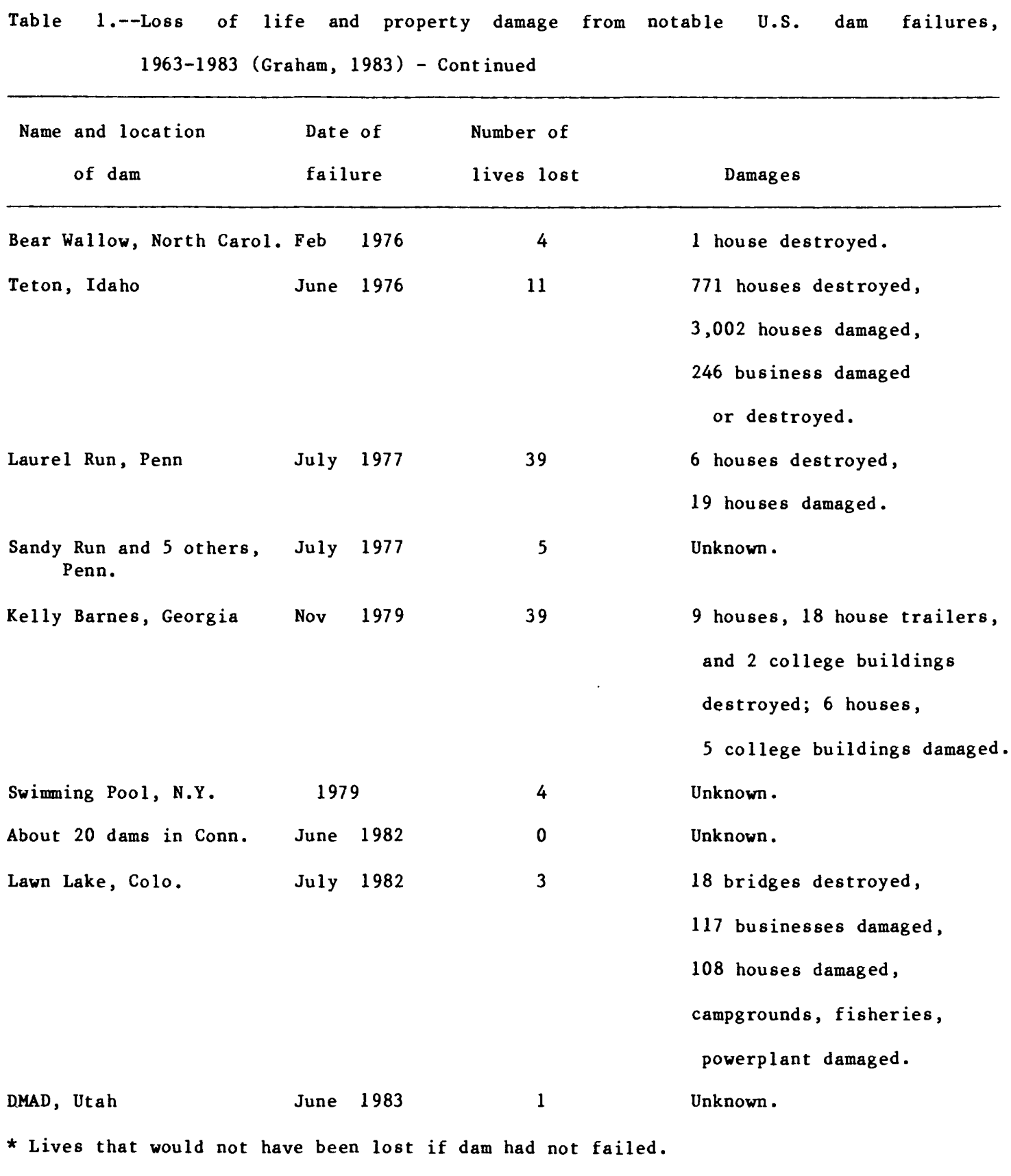


Table 2.--Comparison of warning success for selected dam failures and flash floods (Graham, 1983)

\begin{tabular}{|c|c|c|c|c|}
\hline Event & $\begin{array}{c}\text { Early } \\
\text { detection and } \\
\text { warning }\end{array}$ & $\begin{array}{l}\text { Potential } \\
\text { loss of life }\end{array}$ & $\begin{array}{l}\text { Actual loss } \\
\text { of life }\end{array}$ & $\begin{array}{l}\text { Fatality } \\
\text { rate }(\%)\end{array}$ \\
\hline $\begin{array}{l}\text { Big Thompson, Colo. } \\
\text { (flash flood) }\end{array}$ & No & 2,500 & 139 & 5.6 \\
\hline Laurel Run Dam, Penn. & No & 150 & 39 & 25.0 \\
\hline Kelly Barnes Dam, Georgia & No & 200 & 39 & 20.0 \\
\hline Buffalo Creek, West Va. & Some & 4,000 & 125 & 3.1 \\
\hline Teton Dam, Idaho & Yes & 35,000 & 11 & $<0.1$ \\
\hline $\begin{array}{l}\text { Southern Conn. } \\
\text { June } 1982 \\
\text { ( } 20 \text { dams failed) }\end{array}$ & Yes & Unknown & 0 & 0 \\
\hline Lawn Lake, Colo. & Yes & 4,000 & 3 & $<0.1$ \\
\hline DMAD, Utah & Yes & 500 & 1 & 0.2 \\
\hline
\end{tabular}


The simplest estimation of the peak discharge and attenuation downstream from a dam failure involves empirical data from historic dam failures. Much of the available data on peak discharges from failures of constructed dams is summarized in table 3 . The simplest and earliest relations to be developed involve characteristics of the dam and reservoir. Kirkpatrick (1977) plotted data on height of dam (arithmetic) versus peak discharge $(\log )$ for 21 actual and hypothetical dam failures, and drew what appears to be an average curve through the data points. His equation is:

$$
Q_{\max }=2.297(H+1)^{2.5} \text {, }
$$

where $Q_{\max }$ is peak discharge in cubic feet per second, and $H$ is height of dam infeet. This relation later was revised by the U. S. Soil Conservation Service using data from 13 actual dam failures, and plotted as a power function that appears to be an enveloping curve, although 3 data points are above the curve (Soil Conservation Service, 1981). The equation is:

$$
Q_{\max }=65 \mathrm{H}^{1.85} \text {. }
$$

Dam height versus peak discharge for 31 failures of constructed dams between 1.8 and $84 \mathrm{~m} \mathrm{high}$ is plotted in figure 4 and, listed in table 3 . An envelope curve for flood peaks from all the constructed dams has the equation

$$
Q_{\max }=48 \mathrm{H}^{1.63} \text {, }
$$

where $Q_{\max }$ is peak discharge in cubic meters per second, and $\mathrm{H}$ is dam height in meters. This envelope curve is not plotted in figure 4.

Accuracy of many peak-discharge estimates from dam failures is questionable, and errors of one order of magnitude may exist. If a rapid, conservative assessment of the potential peak discharge from a failed dam is desired, then the envelope curve (equation 3 ) could be used. If the purpose is to compare flood peaks from failures of different types of dams, or to reconstruct past flood peaks from old, failed dams for paleohydrological or sedimentological investigations, then a regression equation is more appropriate. A regression equation using dam height as the independent variable has been developed from the data in table 3 , and plotted in figure 4. The equation is:

$$
\mathrm{Q}_{\max }=10.5 \mathrm{H}^{1.87} ; \mathrm{r}^{2}=0.80,
$$

and the standard error (SE) is 82 percent.

A plot of reservoir volume at time of failure versus peak discharge is shown in figure 5. Sensitivity studies have indicated that reservoir volume as well as dam height are critical factors in the magnitude of damfailure hydrographs (Hagen, 1982; Petrascheck and Sydler, 1984). An envelope curve encompassing all the data points except two (Malpasset Dam, France, point no. 15, and Cascade Lake Dam, Colorado, point no. 30) has the form: 


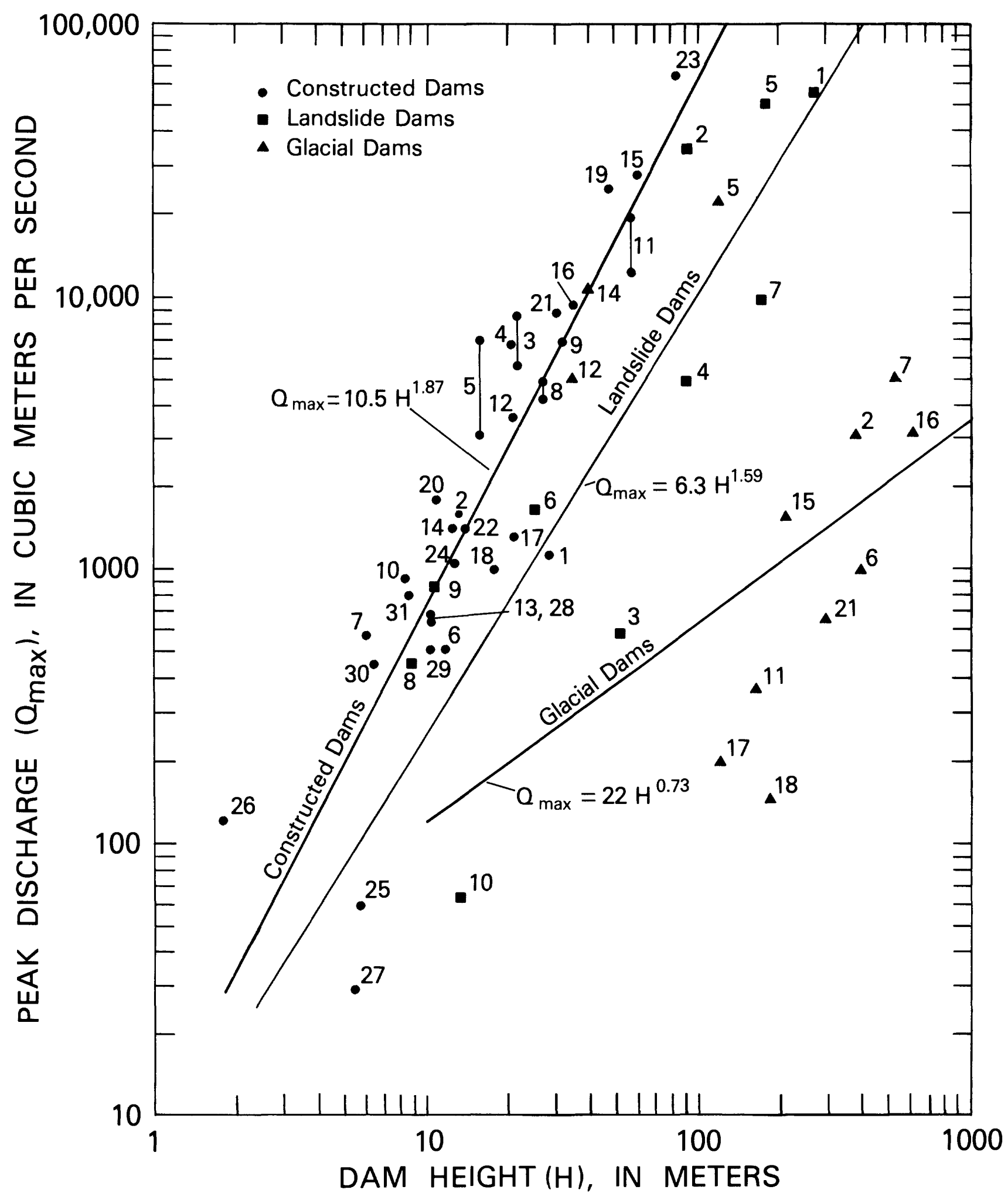

Figure 4. Graph showing dam height ( $H$, in meters) versus peak discharge $\left(Q_{\max }\right.$ in cubic meters per second) for constructed, glacial, and landslide dams with numbers keyed to tables 3,5 and 6 . 


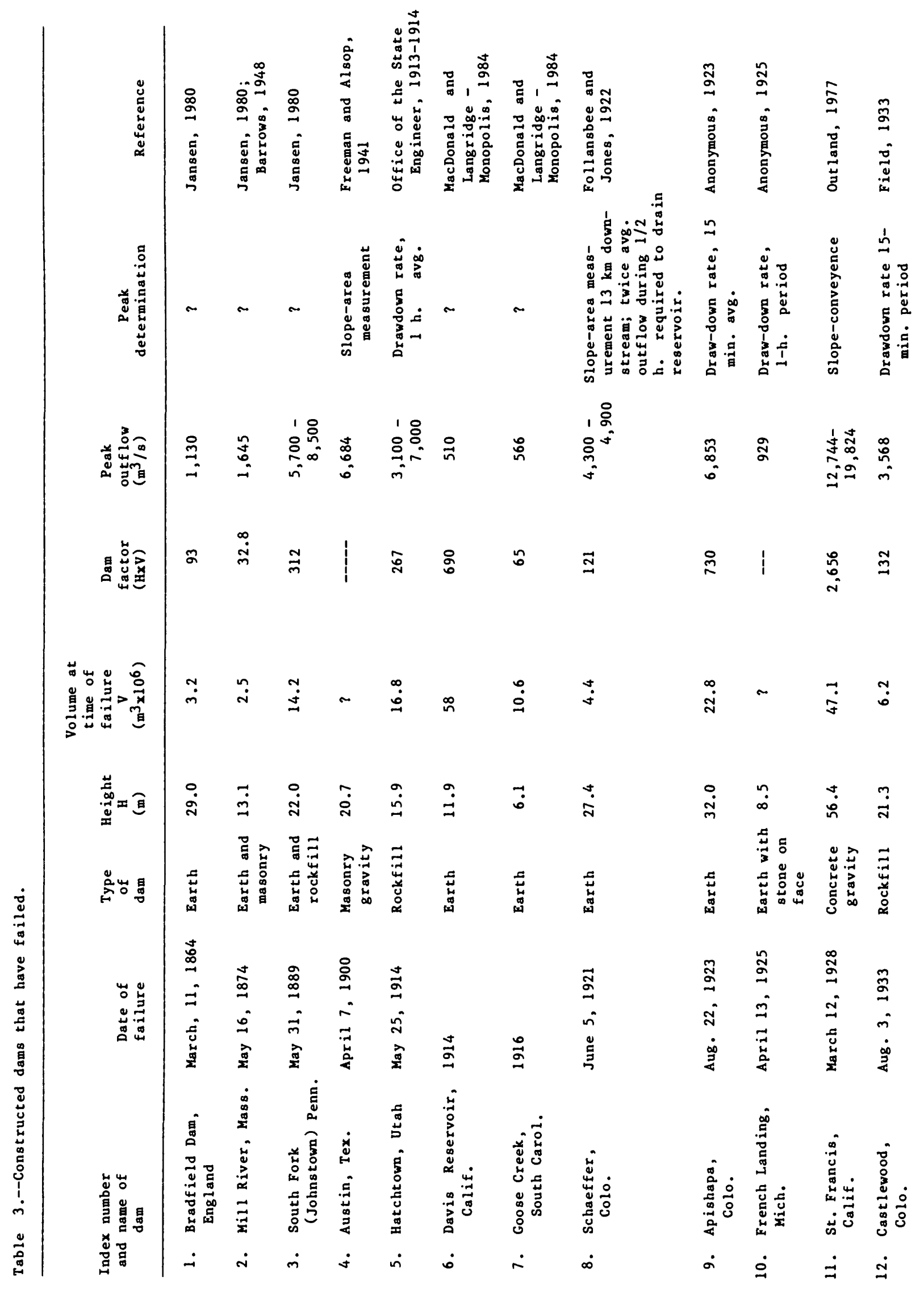




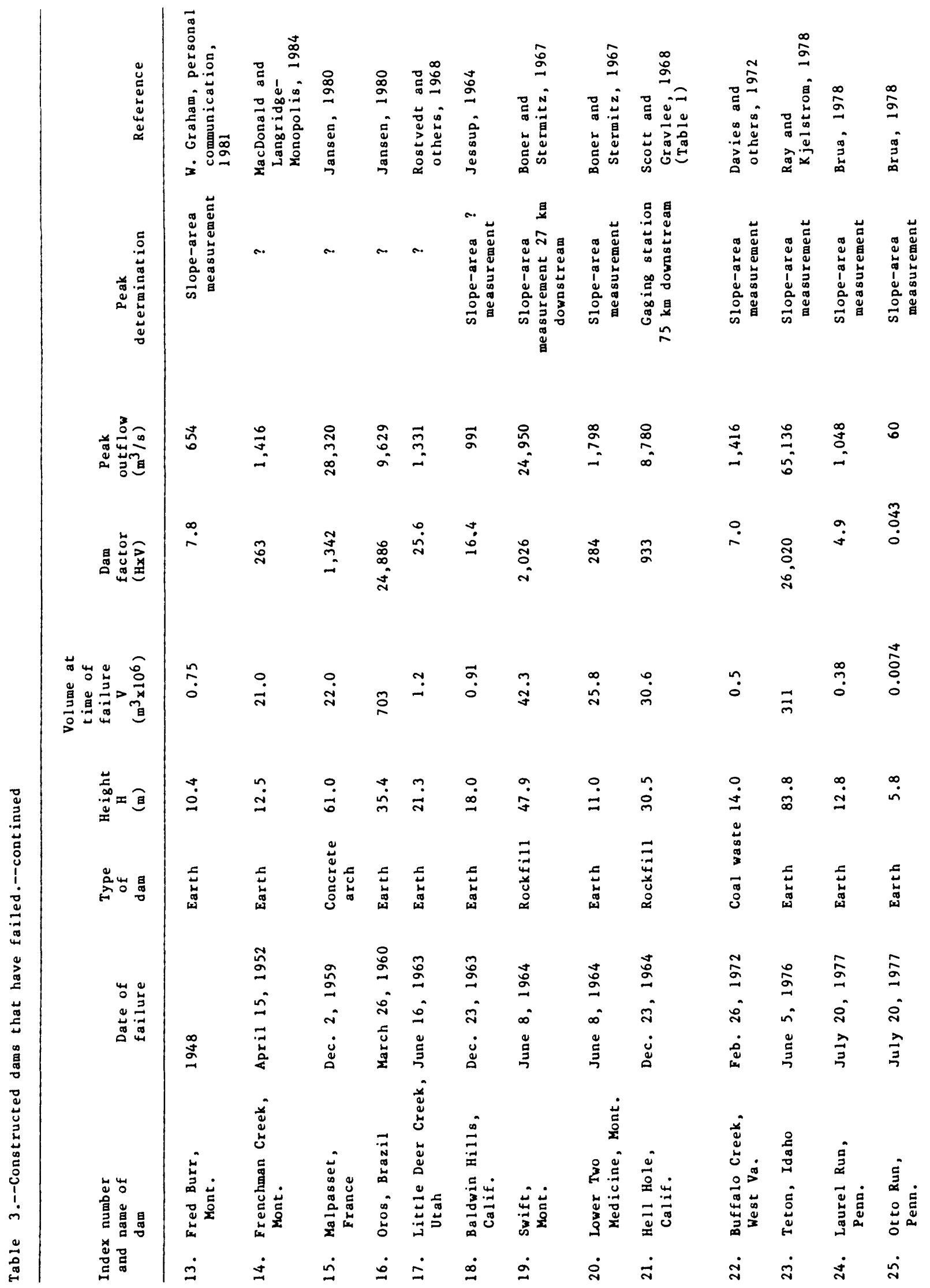




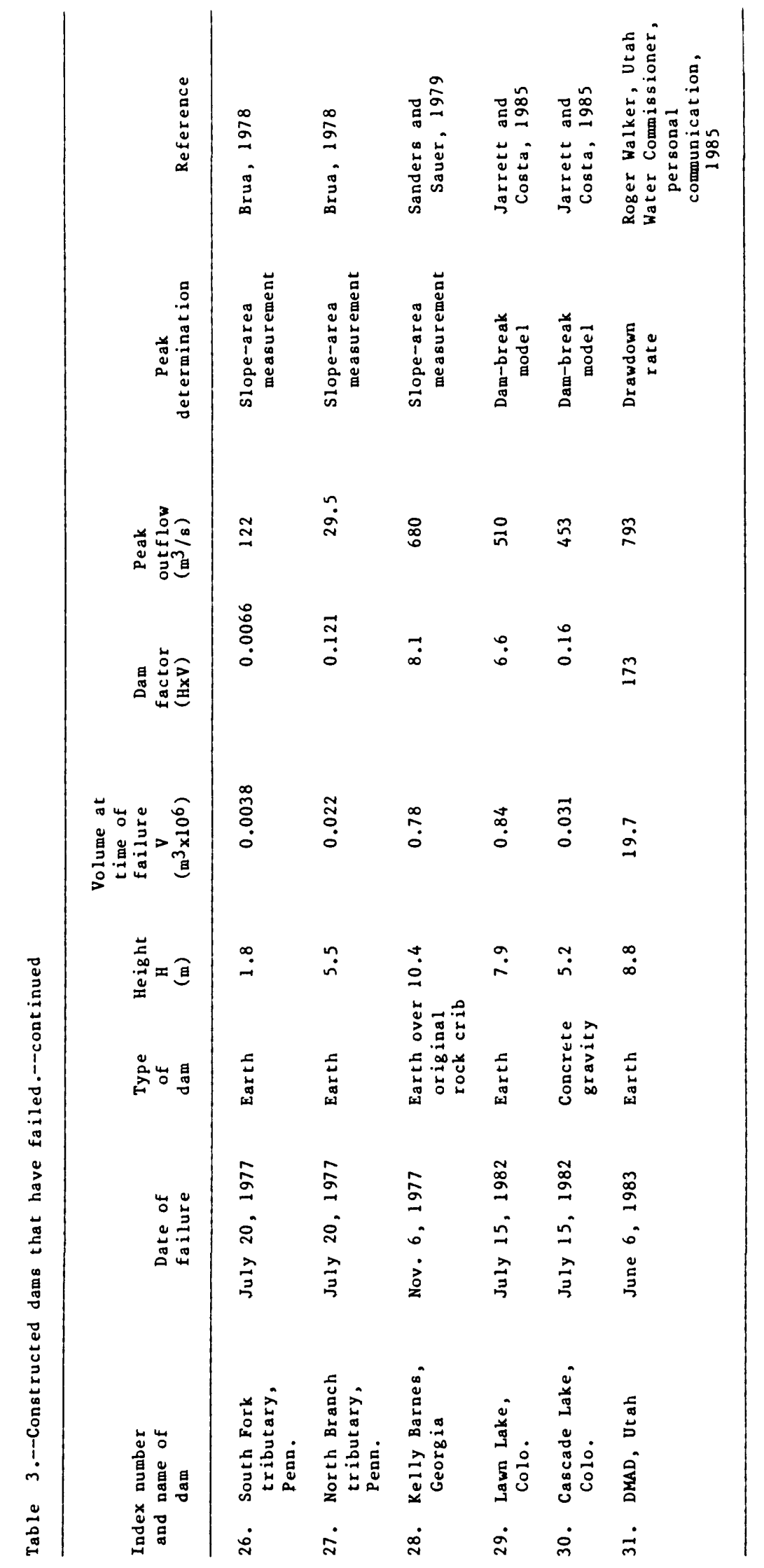




$$
\mathrm{Qmax}=2,950 \quad \mathrm{~V}^{0.57}
$$

where $V$ is reservoir volume at time of failure, in $\mathrm{m}^{3} \times 10^{6}$. This envelope curve is not shown in figure 5.

The Malpasset Dam was a high concrete-arch structure and Cascade Lake Dam was a concrete-gravity dam. These kinds of dams are more susceptible to rapid failure than most of the other types. The sequence of the toppling failure of Cascade Lake Dam, Colorado, is shown in figure 6 . The inflow flood peak leading to the failure was 45 percent of the outflow peak following the failure.

Including the Malpasset and Cascade Lake Dam failures, the envelope curve is:

$$
\mathrm{Qmax}=4,000 \mathrm{v}^{0.57} \text {. }
$$

This envelope curve is not shown in figure 5.

Hagen (1982) and the Committee on the Safety of Existing Dams (1983) developed a criterion for estimating peak discharge based upon the product of dam height (H) and reservoir volume (V). This product ( $H \times V)$ is the dam factor, and is a crude index of the energy expenditure at the dam when it fails. Hagen's equation, based upon seven data points excluding the Malpasset failure, is:

$$
\mathrm{Qmax}=370(\mathrm{HV})^{0.5} \text {, }
$$

and including the Malpasset failure, is:

$$
\mathrm{Qmax}=530(\mathrm{HV})^{0.5} \text {, }
$$

where $\mathrm{V}$ is reservoir volume in acre-feet, and $\mathrm{H}$ is dam height in feet.

Using 29 data points covering a much broader range of reservoir heights and volumes from table 3 , the envelope curve (not plotted) is:

$$
\mathrm{Qmax}=1150(\mathrm{HV})^{0.44}
$$

and the regression equation is:

$$
\mathrm{Qmax}=325(\mathrm{HV})^{0.42} ; \mathrm{r}^{2}=0.75 ; \mathrm{SE}=95 \text { percent }
$$

where $\mathrm{V}$ is reservoir volume in $\mathrm{m}^{3} \times 10^{6}$, and $\mathrm{H}$ is dam height, in meters. The regression curve is plotted in figure 7 .

MacDonald and Langridge-Monopolis (1984) produced a similar relationship to Hagen's (1982), except they relate the product of outflow volume of water during the failure and the difference in elevation of the peak reservoir-water surface and breach base, with peak-outflow discharge. The relation is very similar to that developed by Hagen (1982). 


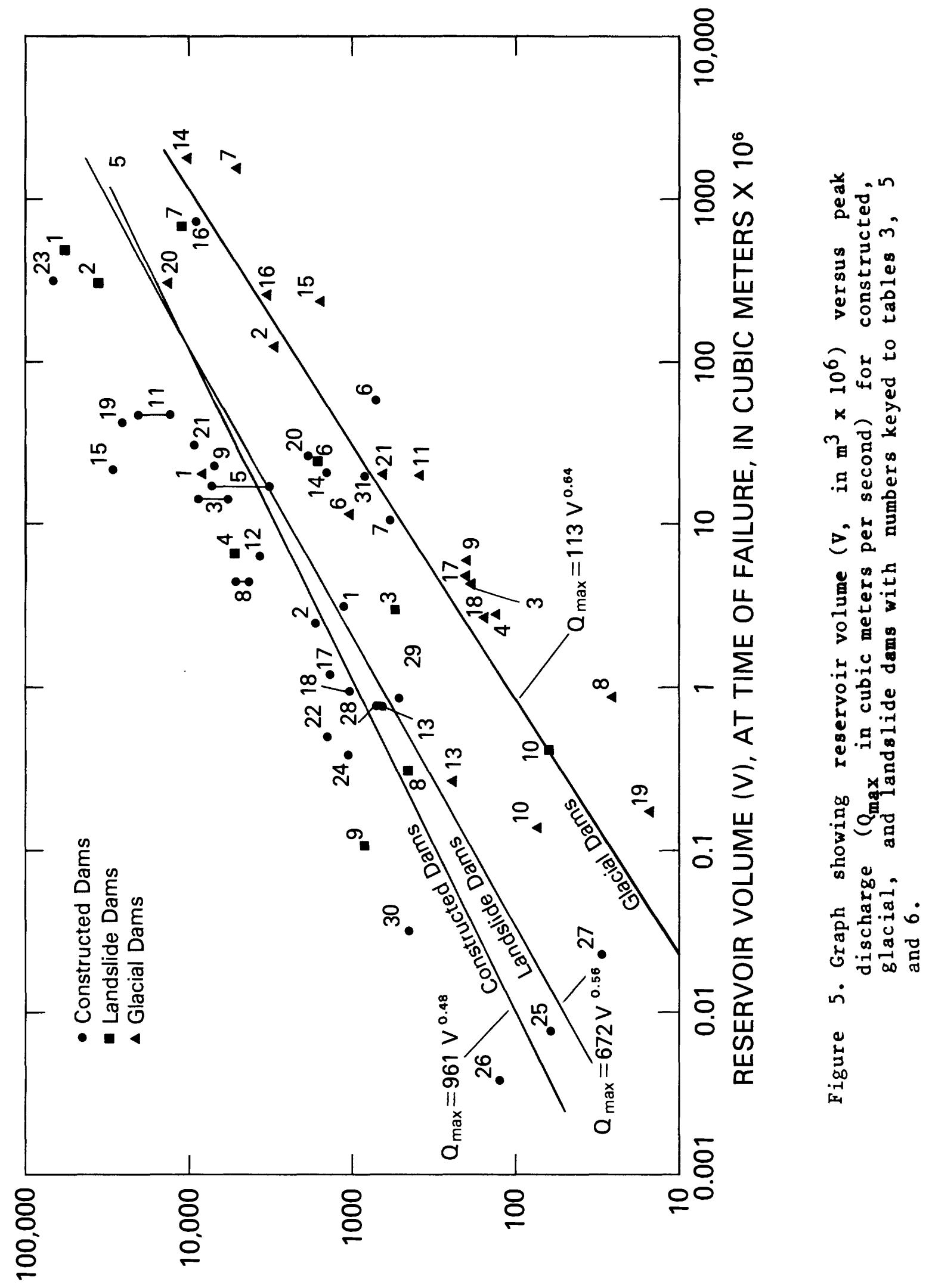

aNOJ 

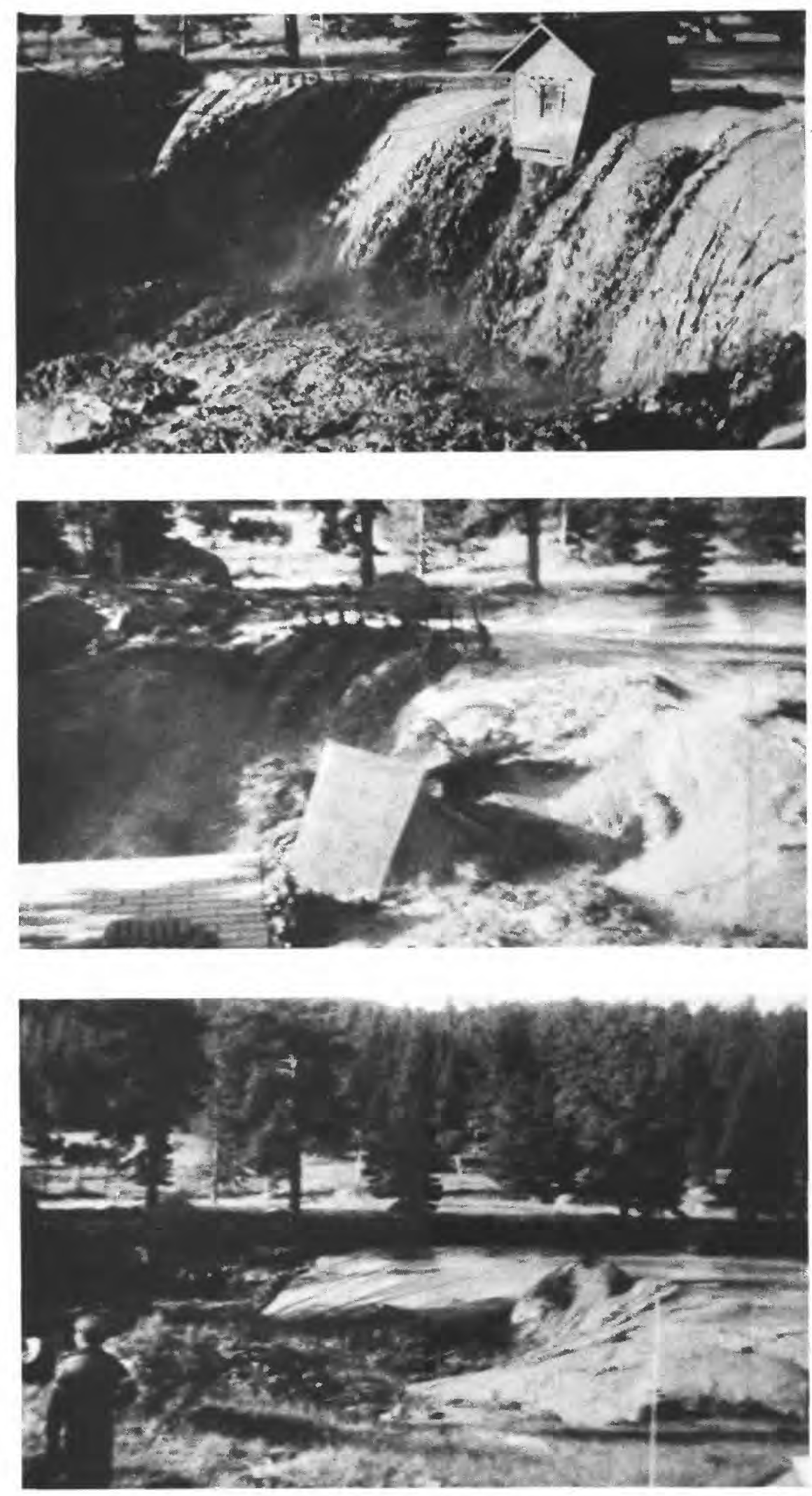

Figure 6. Photographs showing sequence of Cascade Lake Dam failure, Colorado, July 15, 1982 (from Jarrett and Costa, 1985). 


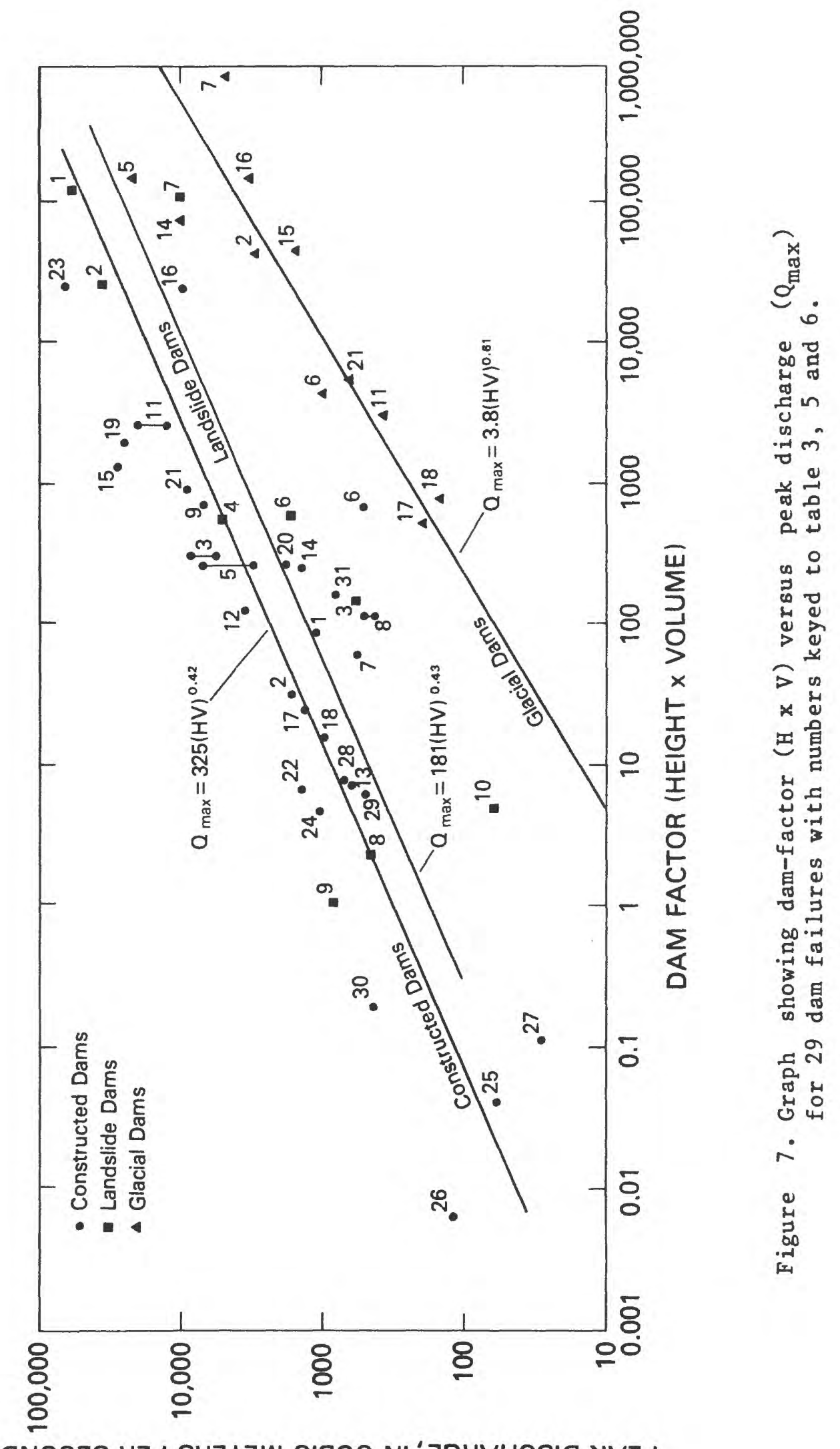

ONOJ 
Simple theoretical estimates of dam-break hydrographs originated with Ritter (1892) who used the approximate Saint-Venant equation but assumed rectangular, horizontal channels with no frictional or turbulent resistance to the unsteady flow. Maximum flood discharge following a dam break is approximated by:

$$
\mathrm{q}=\frac{8}{27} \mathrm{~g}^{1 / 2} \mathrm{Y}^{3 / 2}
$$

where $q$ is breach unit width discharge, $g$ is gravitational acceleration, and $Y$ is reservoir depth upstream of the dam before failure. Since most dam breaches are trapezoidal in shape (MacDonald and Langridge-Monopolis, 1984), the equation has been expanded by Price and others (1977) to:

$$
Q \max =\frac{8}{27} g^{1 / 2} \mathrm{Y}^{3 / 2}(0.4 \mathrm{~b}+0.6 \mathrm{~T})
$$

where Qmax is maximum discharge, $b$ is width of breach base, and $T$ is top width of breach at initial water level. Since this equation ignores frictional and turbulent resistance, computed peak discharges tend to be larger than peak discharges determined by slope-area or draw-down rate methods. Equations 11 and 12 can be rewritten as a simple energy conservation equation for instantaneous disappearance of the dam, where slope and resistance do not initially matter $\left[v=\frac{8}{27}(\mathrm{gy})^{1 / 2}\right]$, where $v$ is velocity (Michael Church, written communication, 1985).

An important control on the downstream flood hydrograph from a failed dam is breach characteristics including size, shape, and time of formation of the breach. MacDonald and Langridge-Monopolis (1984) present a large amount of data on the size and shape of the breach from failed constructed dams. Breach shapes tend to be trapezoidal, with top width four times the dam height, and bottom width two times the dam height (McMahon, 1981). of the three breach characteristics, shape has the least influence on the flood hydrograph.

$$
\text { Time of breach formation can be estimated from } t \leq \frac{1,008 \text { SA }}{W(H)^{1 / 2}} \text { where } t \text { is }
$$
time for breach formation, in seconds, SA is surface area of reservoir, in acres, $W$ is average breach width, in feet, and $H$ is depth of water at time of failure, in feet (Fread, reported in McMahon, 1981). Time of breach formation becomes increasingly insignificant as reservoir volume becomes very large. Size of breach, especially average breach width (W) is a very important variable (Petrascheck and Sydler, 1984). Size of breach is most difficult to estimate for concrete gravity and buttress dams, while for earthfill dams it seems to fall between $1 / 2$ and three times the height of the dam (Johnson and Illes, 1976). For concrete arch dams, breach width is probably the full width of the dam.

Peak discharge resulting from a dam failure can be estimated from a time-dependent relationship:

$$
\begin{aligned}
& Q p=3.1 \mathrm{~W}[\mathrm{c} /(t+c / \sqrt{\mathrm{H}})]^{3} ; \\
& c=23.4 \mathrm{SA} / \mathrm{W}
\end{aligned}
$$


where $Q p$ is peak discharge, $W$ is average breach width ( $f t$ ), $t$ is time (hrs) of breach formation, $H$ is height (H) of the dam, and SA is reservoirsurface area (acres) at the dam crest (Wetmore and Fread, 1981). With this equation, peak discharge sensitivity can be computed for various estimated values of $t$. For a conservative estimate, the maximum expected breach width and minimum expected breach time would be used to estimate peak discharge. Equations 11, 12, and 13 are general forms of the broad-crested wier formula (Brater and King, 1976).

Within the last decade, numerous computer programs have been developed to simulate dam-break hydrographs. Peak discharges, depths, and areas inundated downstream need to be known to minimize loss of 1 ife and property. Two popular examples are the HEC-1 program of the Corps of Engineers, and the National Weather Service DAMBRK model (Fread, 1980). The National Weather Service DAMBRK model, modified by Land (1980b), uses a hydraulic routing procedure based on a nonlinear implicit finite-difference algorthm for the equations of continuity and momentum. References to other programs can be found in Land $(1980 \mathrm{a}, \mathrm{b})$. The purpose of these models is to predict the behavior of flood waters released from a dam failure. The initial outflow hydrograph from a failed dam usually is approximated by a triangle. After the dam-break outflow hydrograph is determined by one of the methods described previously the hydrograph must be routed through the downstream valley. The models usually require river cross sections, Manning's n-values, and upstream and downstream boundary conditions. Model output should include prediction of flood-wave travel time, peak discharges and volumes at different locations downstream, and inundation areas.

Land (1980a) makes some interesting comparisons among four dam-break flood-wave models by using data from three actual dam failures, and provides suggestions for finding the most accurate, stable, and economical models to use. Dam-failure models are constrained by inaccuracies in estimates of breaching characteristics such as timing, size, and shape; by estimations of roughness coefficients, volume losses, debris and sediment effects, and by channel hydraulics inadequately described by onedimensional flow equations. Consequently results of dam-break models can have large and significant errors, and operating the more complicated models can be a difficult task (Land, 1980a). In simulation the user specifies the timing, size, and shape of the final breach. Breach parameters have little impact on flood characteristics far downstream from the dam (Petrascheck and Sydler, 1984). Morphological characteristics of breaches in historic constructed dams are described by Johnson and Illes (1976) and MacDonald and Langridge-Monopolis (1984).

An analysis of some failed dams for which downstream hydraulic measurements were made allows an estimate of attenuation rates based upon empirical data. Available downstream flow data from some failed dams are 1 isted in table 4. Downstream peak discharges are related to peak discharge from the dam failure, and downstream distance from the dam. Attenuation rates as a percentage of upstream discharge are plotted against distance downstream in figure 8. A conservative envelope curve that encompasses all plotted data points for constructed dams, and includes steep, narrow downstream valleys is: 


$$
Q x=\frac{100}{10^{(0.0021 x)}}
$$

where $Q \mathbf{x}=$ discharge as a percentage of the peak discharge at kilometer 0 , and $\mathrm{x}=$ distance downstream from location of peak discharge determination, in kilometers. For broader, more open valleys, a conservative empirical enveloping curve has the form,

$$
Q x=\frac{100}{10^{(0.0052 x)}}
$$

Knowledge of the valley geometry downstream should be used to modify the previous equations as necessary. Wide flood plains and high infiltration rates may lead to more rapid attenuation than the curves would indicate. Flood elevations and inundation areas can be determined from depth-discharge and depth-area curves.

\section{NATURAL DAMS}

A wide variety of types of natural dams have failed, producing large floods. Hutchinson (1957) provides a comprehensive overview of the origins of lakes and includes discussion of failures of natural dams. The most common types of natural dams that have failed producing large floods are ice dams, morainal dams, volcanic flow dams, and landslide dams.

\section{Joku1hlaups}

Jokulhlaup ('glacier burst') is an Icelandic term for a flood caused by the sudden and often catastrophic release of water impounded within or behind glacial ice (Thorarinsson, 1953). The largest flood known to have occurred on the surface of the Earth, the "Spokane Flood" in eastern Washington, originated from the sudden release of water from Glacial Lake Missoula in the valley of the Clark Fork River in western Montana when an ice dam formed by a lobe of the Cordilleran Ice Sheet failed between 16,000 and 12,000 years ago (Baker, 1973). The lake had a volume of $2 \times 10^{12} \mathrm{~m}^{3}$ and failure of the ice dam produced a flood with an estimated peak discharge of $21 \times 10^{6} \mathrm{~m}^{3} / \mathrm{s}$ (Baker, 1973).

Joku1hlaups can occur in any area covered by continental or valley glaciers. They have caused large loss of life and property damage in many places throughout the world including Iceland (Thorarinsson, 1953, 1957); northern India (Hewitt, 1982); Pakistan (Nash and others, 1985); Peru (Lliboutry and others, 1977); Norway (Aitkenhead, 1960); Alaska (Post and Mayo, 1971); Switzerland, France, and Italy (Eisbacher and Clague, 1984); and Canada (Clarke, 1982; Young, 1980).

In a study of more than 50 jokulhlaups in the Alps, over 95 percent occurred in the months of June to September, inclusive, with maxima in June and August (Tufne11, 1984). Glacial lakes often drain periodically, which 


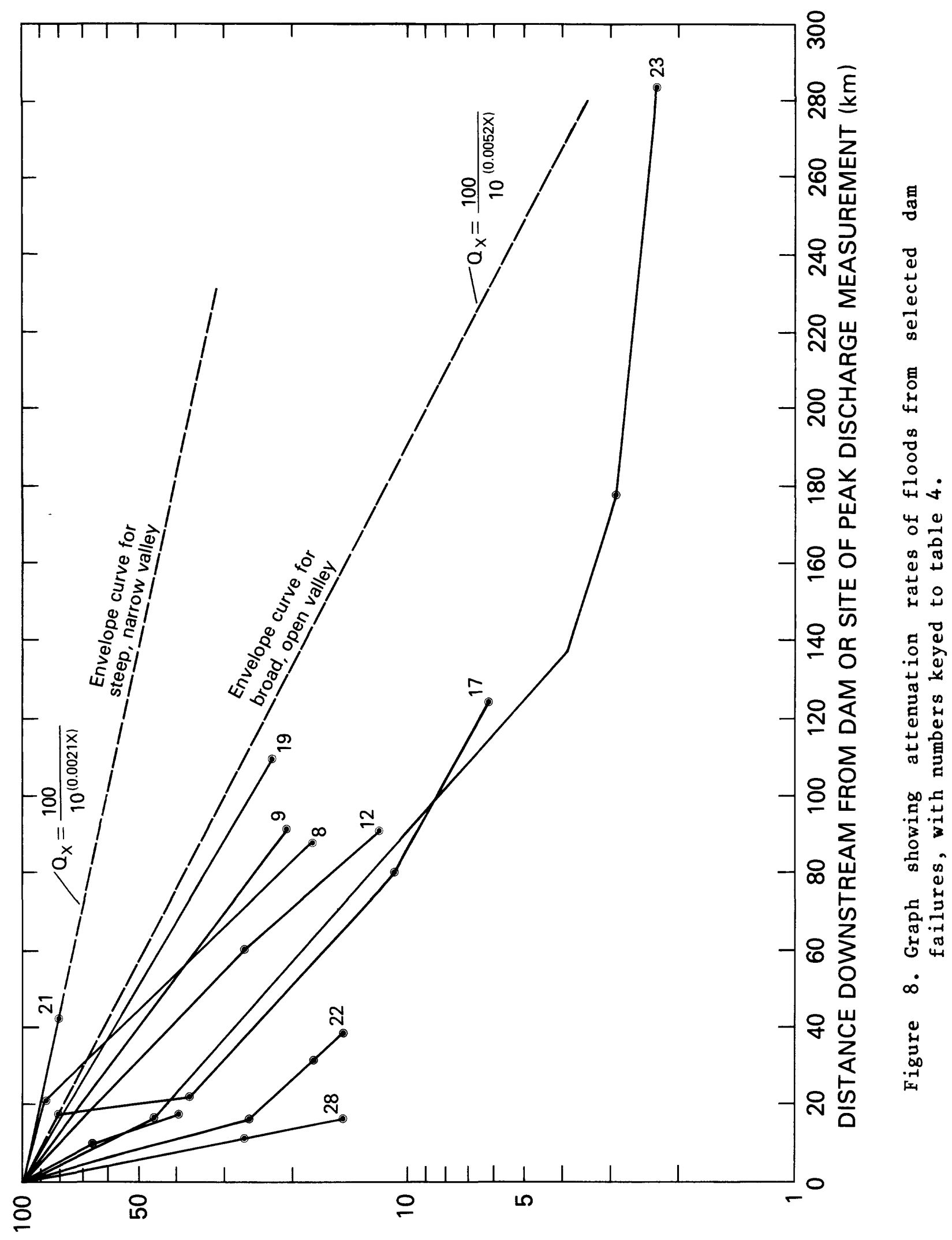

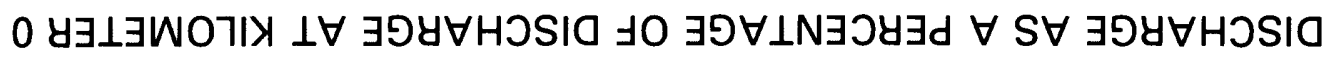


Table 4.--Attenuation rates from some historic dam-failure floods (in part from Graham, 1980).

\begin{tabular}{|c|c|c|c|}
\hline $\begin{array}{c}\text { Name of } \\
\text { Dam } \\
\text { (index number from } \\
\text { table } 3 \text { ) }\end{array}$ & $\begin{array}{c}\text { Cumulative } \\
\text { distance along } \\
\text { flood plain, in kilometers }\end{array}$ & $\begin{array}{c}\text { Peak discharge } \\
\left(\mathrm{m}^{3} / \mathrm{s}\right)\end{array}$ & $\begin{array}{l}\text { Percentage of } \\
\text { discharge at } \\
\text { river-kilometer } 0\end{array}$ \\
\hline Schaeffer, Colo. & 0 & 4,900 & 100 \\
\hline \multirow[t]{2}{*}{ (no. 8) } & 21 & 4,330 & 88 \\
\hline & 88 & 880 & 18 \\
\hline Apishapa, Colo. & 0 & 6,850 & 100 \\
\hline (no. 9) & 91 & 1,420 & 21 \\
\hline Cast lewood, Colo. & 0 & 3,570 & 100 \\
\hline \multirow[t]{2}{*}{ (no. 12) } & 60 & 960 & 27 \\
\hline & 91 & 425 & 12 \\
\hline \multirow{5}{*}{$\begin{array}{c}\text { Little Deer C } \\
\text { (no. 17) }\end{array}$} & Utah & 1,330 & 100 \\
\hline & 17 & 1,100 & 82 \\
\hline & 22 & 500 & 37 \\
\hline & 80 & 150 & 11 \\
\hline & 124 & 85 & 6.3 \\
\hline Swift, Mont. & 0 & --- & -- \\
\hline \multirow[t]{2}{*}{ (no. 19) } & 35 & 24,950 & 100 \\
\hline & 144 & 5,780 & 23 \\
\hline Hell Hole, Calif. & 0 & --- & --- \\
\hline \multirow[t]{2}{*}{ (no. 21) } & 75 & 8,780 & 100 \\
\hline & 117 & 7,165 & 82 \\
\hline
\end{tabular}


Table 4.--Attenuation rates from some historic dam-failure floods (in part from Graham, 1980).--continued

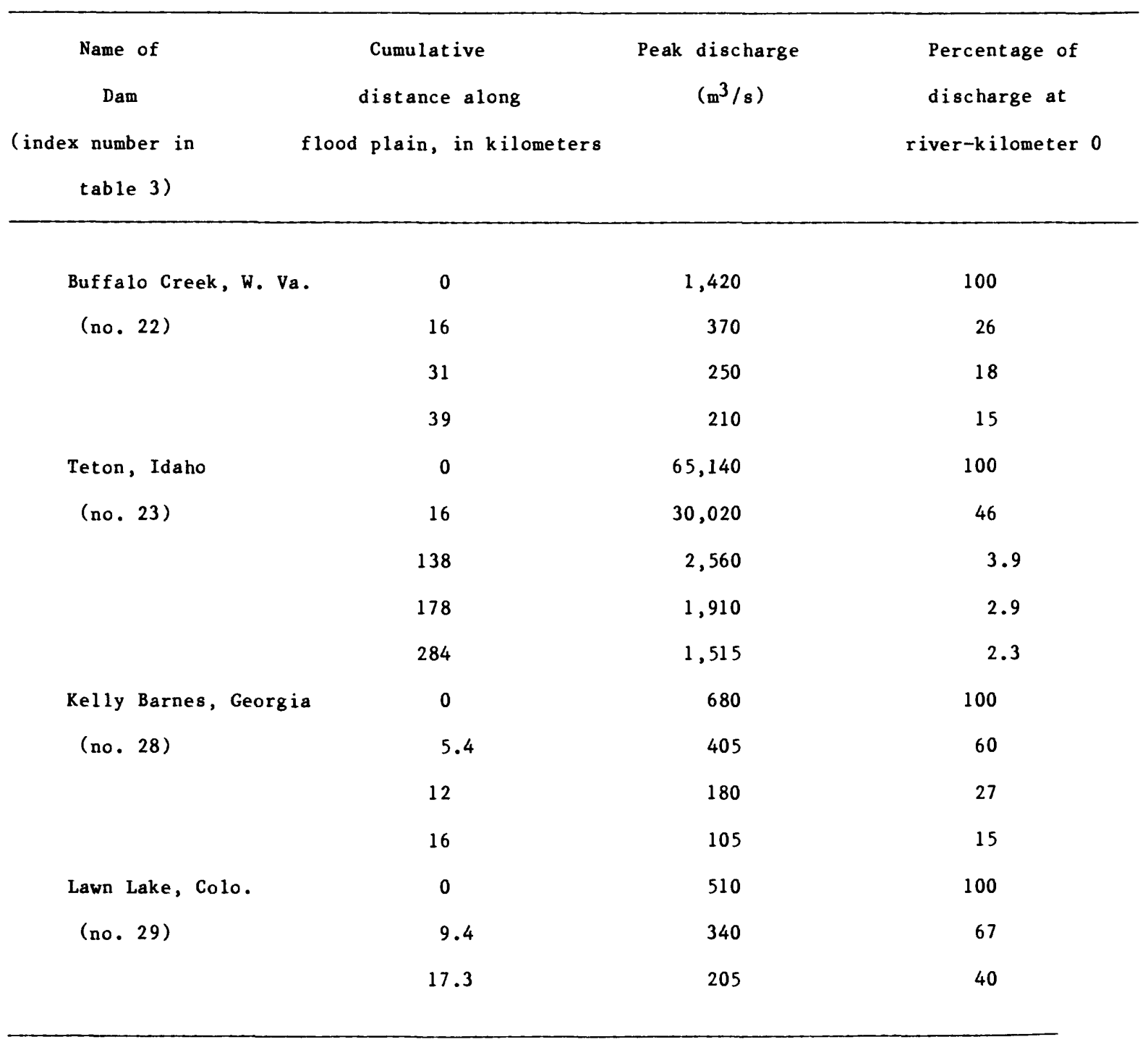


suggests that the depth of water (and consequent hydrostatic pressure) may be the primary factor controlling when a lake drains. The release of glacier-dammed lakes can occur by the formation of a drainage channel under, through, or over the ice. Several proposed mechanisms for failure of ice-dammed lakes include (I) slow plastic yielding of ice from hydrostatic pressure differences between the lake and adjacent, less-dense ice (2) raising of the ice barrier by hydrostatic flotation, (3) crack progression under combined shear stress from glacier flow and high hydrostatic pressure, (4) drainage through small, pre-existing channels at the ice-rock interface and consequent enlargement of ice tunnels by melting by heat in the lake water, and heat produced from kinetic energy of the water from the rapidly draining lake; (5) water overflowing the ice dam, generally along the margin; (6) subglacial melting by volcanic heat; and (7) weakening of the ice dam by earthquakes (Post and Mayo, 1971). Factors (1) through (4) are controlled by thickness of the ice dam, which determines the necessary pressure for floatation, and controls ice dynamical behavior such as tunnel closure rate and crevasse behavior. Lake depth, meanwhile, is limited by the elevation of the lowest bedrock divide or col.

When a lake drains, drainage tunnels freeze in the winter and runoff collects behind the ice dam in the spring and summer, during which time the ice dam may fail again. The characteristics and behavior of ice-dammed lakes can change drastically as ice advances or retreats in response to local climate variations. Lakes dammed by polar and subpolar ice in cold regions normally drain supraglacially or margina1ly through downmelting of the outlet channel, while ice dams in more temperate climates are more liable to sudden englacial or subglacial breaching (Blachut and Bellantyne, 1976 ).

Jokulhlaups can produce enormous floods (Table 5). The largest floods seem to be outbursts produced by subglacial melting of ice by volcanoes. The most intense observed floods occur from Myrdalsjokul1 in Iceland where peak discharges may exceed $100,000 \mathrm{~m}^{3} / \mathrm{s}$ (Thorarinsson, 1957). Hypothetica1 hydrographs of two types of jokulhlaups are shown in figure 9. Dams that burst suddenly are characterized by a steep rising $1 \mathrm{imb}$, sharp peak, and a steep recession $1 \mathrm{imb}$ (Young, 1980). Floods produced by progressive en largement of veins and channels by passing waters have more gradually rising $1 \mathrm{imbs}$, sharp peaks, and steep recessional 1 imbs (Haeber1i, 1983). Some examples of actual jokulhlaup hydrographs can be found in Thorarinsson (1953) and Stone (1963). The time of year when a jokulhlaup occurs can be an important factor in determining the magnitude of the flood. In January 1969, the drainage of a glacial lake into the Kenai River, Alaska, fractured the river ice and formed large ice jams that plugged the channel, resulting in severe flooding (Post and Mayo, 1971).

The timing and potential magnitude of jokulhlaups only can be crudely estimated. If the hydrostatic flotation theory of Thorarinsson (1953) is applicable, subglacial drainage becomes possible when the hydrostatic pressure of water from a lake exceeds the ice overburden pressure in a dam. This occurs when the depth of water in the glacial lake reaches about 0.9 times the height of the ice barrier. Knowing the height of the ice barrier 


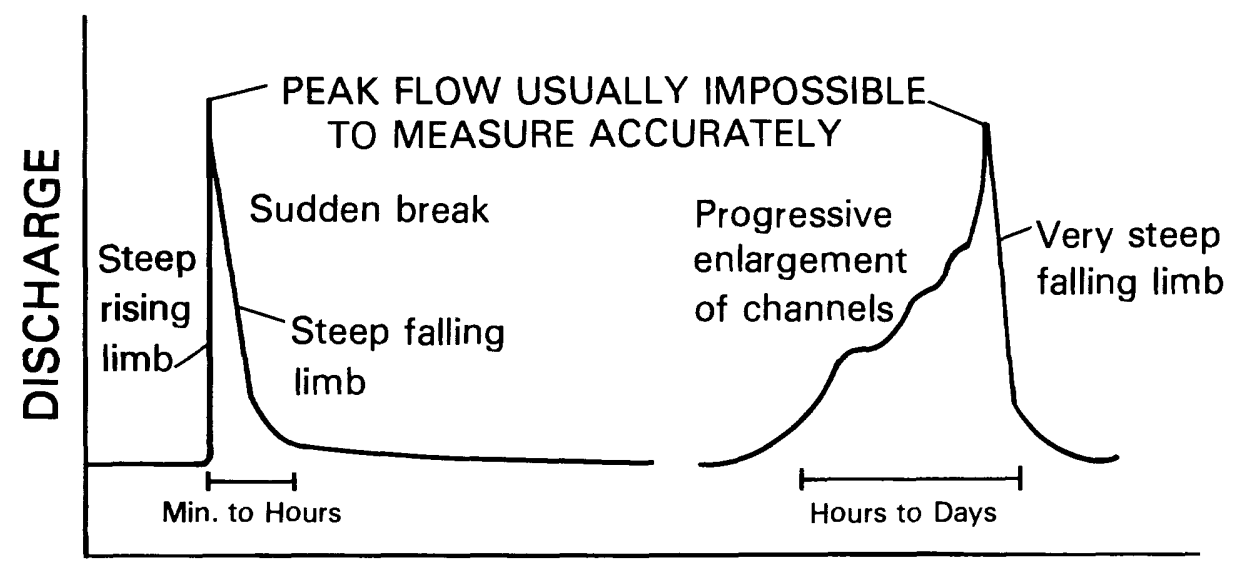

TIME

Figure 9. Generalized hydrographs of jokulhlaups. 


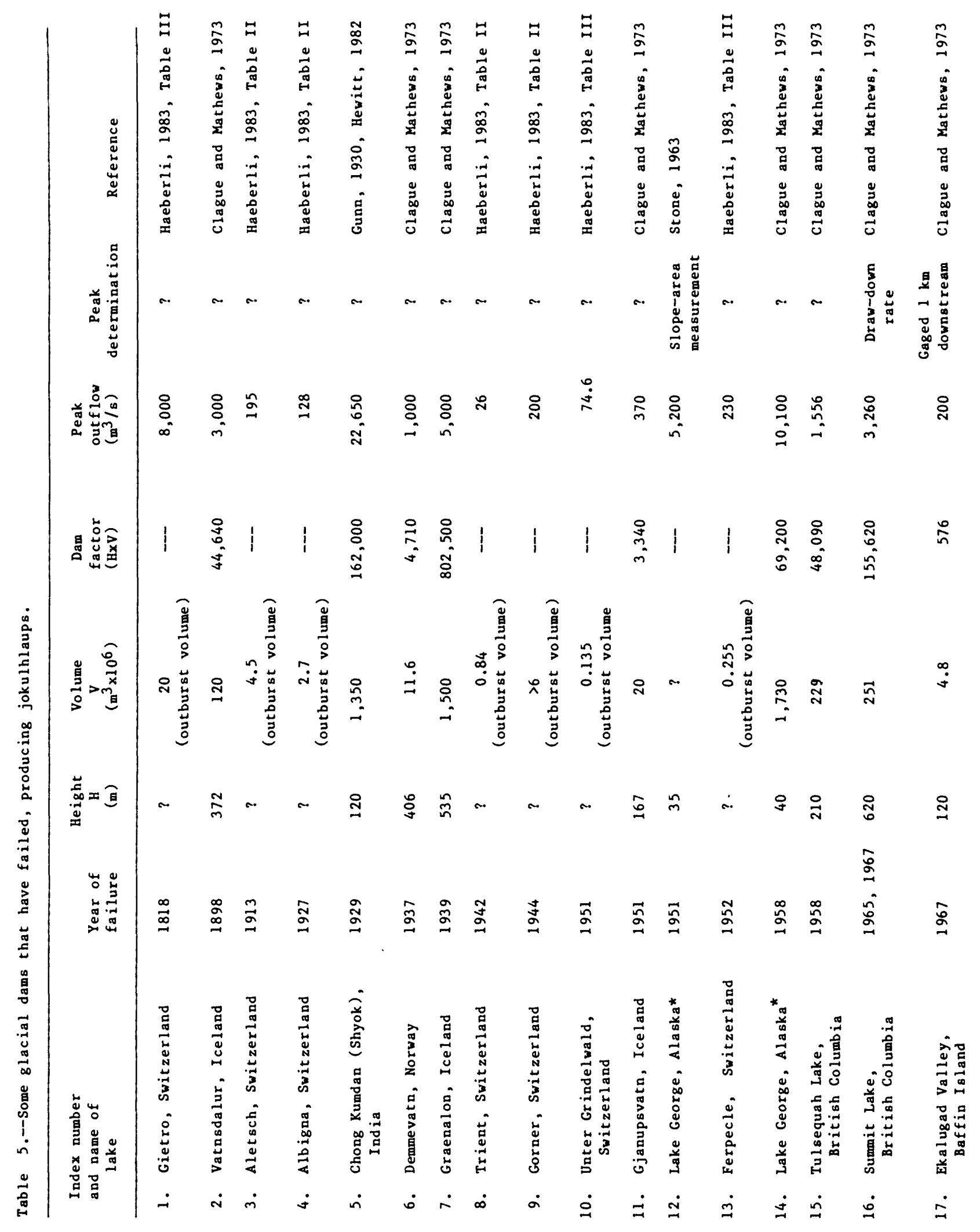




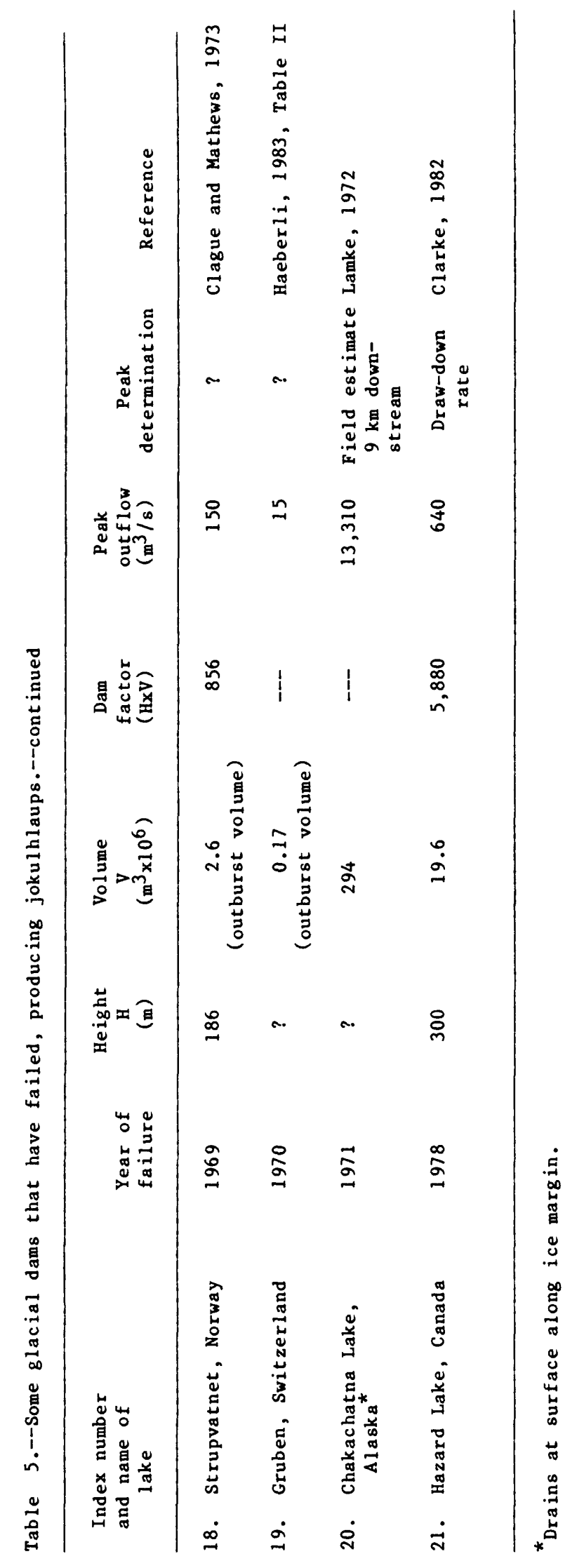


and monitoring depth of lake water may allow warnings to be given when critical depths are approached. Unfortunately, jokulhlaups can occur long before critical depths for flotation are reached (Mathews, 1965).

The magnitude of jokulhlaups can be estimated from the empirical relationship between lake volume and peak discharge developed by Clague and Mathews (1973):

$$
\mathrm{Qmax}=75 \mathrm{v}^{0.67} ; \mathrm{r}^{2}=0.96
$$

where Qmax is maximum discharge in $\mathrm{m}^{3} / \mathrm{s}$ and $\mathrm{V}$ is lake storage in $\mathrm{m}^{3} \times 10^{6}$. A more comprehensive data set that does not include the Pleistocene Lake Missoula flood is in table 5. Using these data, the regression equation is :

$$
Q \max =113 v^{0.64} ; \quad r^{2}=0.80 ; S E=106 \text { percent. }
$$

The curve is plotted in figure 5. Because glacial dams can drain in a variety of ways, dam height does not seem to be a good indicator of peak discharge. A regression equation using. data from table 5 is:

$$
Q_{\max }=21.6 \mathrm{H}^{0.73} ; \mathrm{r}^{2}=0.08 ; \mathrm{SE}=236 \text { percent } \text {. }
$$

However the dam-factor ( $H \times$ V) regression equation has a much lower standard error:

$$
\mathrm{Q}_{\max }=3.8(\mathrm{HV})^{0.61} ; \mathrm{r}^{2}=0.79 ; \mathrm{SE}=75 \text { percent. }
$$

This curve is plotted in figure 7.

Theoretical investigations of glacier-outburst floods have been undertaken by Mathews (1973), Nye (1976), and Clarke (1982). These hydraulic-thermodynamic models are based upon tunnel geometry, continuity, energy conservation, and heat transfer, and require estimation or direct measurement of several critical parameters, including roughness coefficients and lake temperatures. These models do not do equally well in al1 circumstances. Models of jokulhlaups are subject to many of the same difficulties and uncertainities as models of constructed dam failures. The phenomena are more complex than can easily be analyzed, and therefore models are not very reliable.

Moraina1 Dams

Terminal or recessional moraines in glaciated areas may be sufficiently we11-preserved that they dam the stream that replaces the melting glacier. The advances and retreats of mountain glaciers in different parts of the world over the past few hundred years have created a large number of sma11, unstable morainal dams. These dams subsequent $1 y$ may fail by overtopping and erosion of the dam by large runoff events, or large waves (fig. 10). Most constructed dams are zoned to minimize leakage, and riprapped to minimize surface erosion. However, morainal and landslide dams are heterogenous mixtures of a variety of particle sizes. 


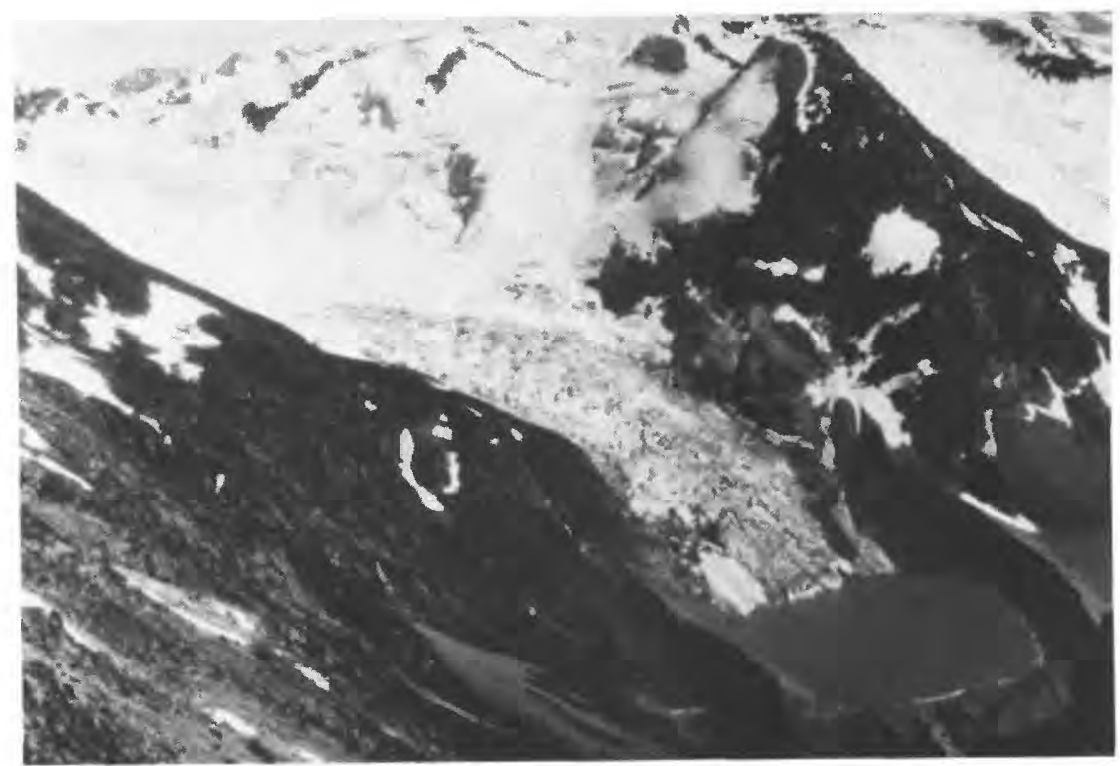

Figure 10. A. Aerial photograph of Nostetuko Lake and Cumberland Glacier, British Columbia, Canada, in July, 1977. (Photo by J. M. Ryder, courtesy of Michael (hurch).

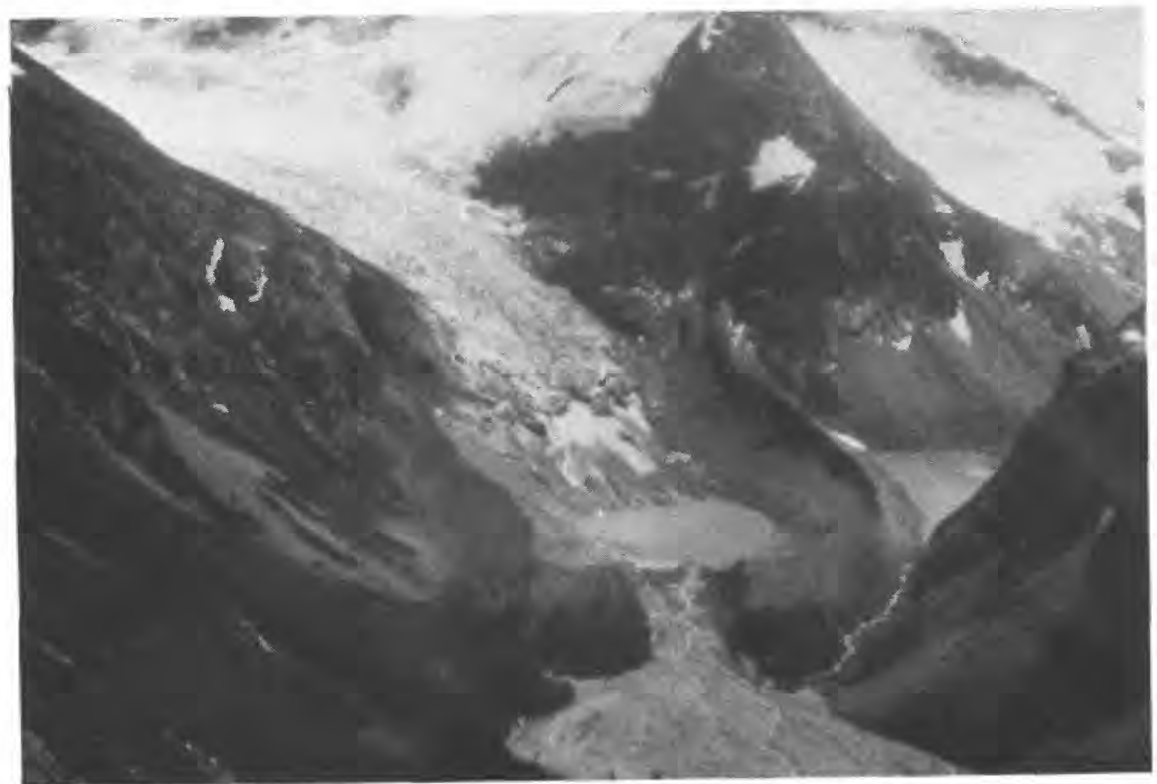

B. Aerial photograph of Nostetuko Lake and Cumberland Glacier, British Columbia, Canada, in August, 1983, after the morainal dam was breached. (Photo courtesy of Michael Church). 
When a morainal or lands lide dam is breached, downcutting commences and erosion of a breach usually begins as headward-eroding cuts. Eventually the headward erosion reaches the impounded water, lowering the outlet and allowing more water to escape.

In 1874, a proglacial lake that had formed behind a Little Ice Age terminal moraine of the Madatschferner glacier in Austria, breached its unstable morainal dam and caused flooding in the valley below (Eisbacher and Clague, 1984, p. 131). Breaches in young morainal dams also have occurred from waves produced by large rock and ice falls into lakes and subsequent overtopping and erosion of the natural dam. This phenomenon has been described in Austria (Eisbacher and Clague, 1984, p. 131); Peru (L1 iboutry and others, 1977); and Canada (Blown and Church, 1985) (fig. $10)$.

Many lakes dammed by frontal moraines have no defined outlets. Outflow occurs through springs located in the moraine, and discharges vary with lake levels. In these situations, piping failures are a potential hazard. Hundreds of thousands of dollars have been spent trying to lower lake levels, and thus to minimize failures of morainal dams in the Cordillera Blanca, Peru, following a major ice retreat in the early to mid 1900's (L1iboutry and others, 1977).

\section{Volcanic Dams}

Floods can originate from the breaching of natural dams formed by lava flows (Finch, 1937; Cotton, 1944) or pyroclastic flows (Aramaki, 1981; Scott and Janda, 1982; Jennings and others, 1981), or from the breaching and expelling of volcanic crater lakes (Zen and Hadikusumo, 1965; Nairn and others, 1979).

On March 28 and 29, 1982, E1 Chichon Volcano in southern Mexico erupted. A pyroclastic flow dammed the Rio Magdalena southwest of the volcano, forming a lake $5 \mathrm{~km}$ long and several million cubic meters in volume (Silva and others, 1982). On May 26, 1982, the pyroclastic dam failed, draining the lake in about 1 hour and sending a flood of very hot water downstream. Bridges, a village, and a hydroelectric plant downstream were damaged. Ten kilometers from the dam, a floodwater temperature of 82 degrees Celsius was measured. At a hydroelectric plant $35 \mathrm{~km}$ downstream, one worker was killed and three were badly burned by the hot flood waters (52 degree Celsius). The breaching of a large pyroclastic dam that was formed by the 1783 eruption of Asama Volcano, Japan, resulted in the destruction of more than 1,200 houses and the loss of more than 1,200 lives (Aramaki, 1981).

In 1912, a large volcanic eruption occurred in the Valley of Ten Thousand Smokes, Katmai National Park, Alaska. A cluster of phreatic craters dammed a $1.5 \mathrm{kilometer-10ng} \mathrm{lake} \mathrm{atop} \mathrm{the} \mathrm{tuff.} \mathrm{It} \mathrm{is} \mathrm{estimated}$ that the dam failed in the summer of 1912 or 1913 (Hildreth, 1983). The flood scoured the ash-flow surface to depths of 1 to 2 meters, transported 50 -centimeter-diameter blocks of welded tuff over 20 kilometers, and deposited 1 to 8 meters of sediment in the lower parts of the valley (Hildreth, 1983). 
Landslide dams

Landslides that move into stream valleys and dam rivers are very common, yet no comprehensive investigation has ever been undertaken to investigate this world-wide phenomena. If a landslide dam fills and overspills, rapid erosion of the landslide deposits can lead to catastrophic flood discharges and great loss of 1 ife and property. Landslide dams form in all kinds of physiographic settings, ranging from rock avalanches in steep mountainous terrains, to quick-clay failures in flat river lowlands. Earthquakes appear to be a significant cause of landslides that dam valleys (Adams, 1981; Keefer, 1984). One of the earliest reported landslide dams formed in $563 \mathrm{AD}$ in the St. Barthelemy Basin, Switzerland. The debris blocked the upper Rhone River and the subsequent failure killed many people as floodwaters flowed into Lake Geneva (Eisbacher and Clague, 1984).

Probably the greatest landslide dam failure disaster was the Indus River landslide dam failure of 1841 (Mason, 1929). During the winter of 1840 and 1841, part of Nanga Parbat collapsed into the Indus River following an earthquake. The landslide dam formed a lake $305 \mathrm{~m}$ deep and 64 $\mathrm{km}$ long. In June, 1841, the dam was breached by the Indus, and a tremendous flood resulted. At Attock, over $400 \mathrm{~km}$ downstream, the water rose to over $30 \mathrm{~m}$ deep, engulfing a Sikh army camp on the floodplain near Attock, killing 500. Hundreds of villages were washed away, and thousands of lives were lost (Mason, 1929).

Following the May 1980 eruption of Mount St. Helens, Washington, debris-avalanche deposits impounded three large lakes (Coldwater Creek, South Fork Castle Creek, and Spirit Lakes) and several smaller ones (fig. 11). Coldwater Creek Lake, had it been allowed to fill naturally, would have developed an estimated maximum volume of $123 \times 10^{6} \mathrm{~m}^{3}$ by late 1981 . If this dam had overtopped, Dunne and Fairchild (1983) estimated that a vertical erosion rate of $0.3 \mathrm{~m} / \mathrm{minute}$ would occur, developing a rectangular breach with width-depth ratio of two, and a maximum incision of $30 \mathrm{~m}$. Clear-water peak discharge through the breach was calculated using the broad-crested weir formula to be $14,000 \mathrm{~m}^{3} / \mathrm{s}$ within 100 minutes, and $18,000 \mathrm{~m}^{3} / \mathrm{s}$ after bulking up the floodwaters with easily eroded unconsolidated sediment. The U.S. Army Corps of Engineers constructed a permanent spillway for Coldwater Creek and South Fork Castle Creek Lake during the summer of 1981 that stabilized their volumes at $82.6 \times 10^{6} \mathrm{~m}^{3}$ and $24 \times 10^{6} \mathrm{~m}^{3}$ respectively (Schuster, 1984).

For the debris avalanche dam impounding Spirit Lake, the expected flood hydrograph from the hypothetical failure of the debris dam was simulated with the National Weather Service DAMBRK model (Fread, 1980) and appropriate revisions (Land, 1980a) for an overtopping failure (Jennings and others, 1981), and for a piping failure at lower reservoir levels (Swift and Kresch, 1983). Dunne and Fairchild (1983) employed the same procedure of estimating erosion rates, breach characteristics, and peak discharge that they used for Coldwater Creek Lake. Clear-water peak dischange values were $17,400 \mathrm{~m}^{3} / \mathrm{s}, 15,000 \mathrm{~m}^{3} / \mathrm{s}$, and $15,600 \mathrm{~m}^{3} / \mathrm{s}$ 


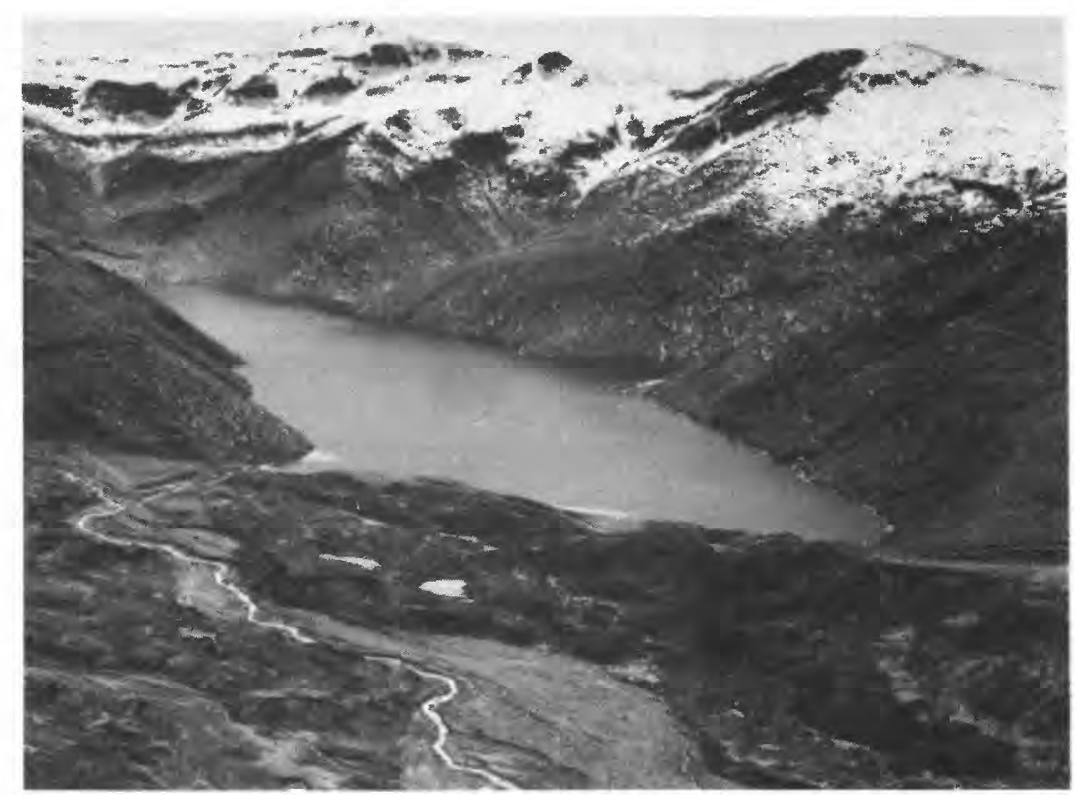

Figure 11. Photograph of Castle Lake, Mount St. Helens, Washington, dammed by a debris avalanche deposit. Debris avalanche moved from left to right in photo. An artificial spillway was cut into the right embankment. (April, 1984) (Photo courtesy of R. L. Schuster). 
respectively. It was expected that these clear-water peak flows would quickly entrain large volumes of sediment, so when the flows were routed downstream, large volumes of sediment were added to simulate muddy floodwaters or debris flows.

The hazard presented by the volcanic debris-avalanche dam of Spirit Lake has been mitigated by constructing a permanent drainage tunnel in bedrock at a cost of $\$ 14$ million (Sager and others, 1984; Schuster, 1985).

Numerous smaller lakes were formed by the unstable volcanic debris surrounding Mount St. Helens, and several breakout floods have been produced. A landslide dam that accumulated water from Castle and Maratta Creeks failed on August 19, 1980. The floodwaters were reimpounded in another dam near E1k Rock. This dam was overtopped and breached on August 27, 1980 , releasing $0.3 \times 10^{6} \mathrm{~m}^{3}$ of water into the North Fork Toutle River. The estimated flood peak was $450 \mathrm{~m}^{3} / \mathrm{s}$, and $2.8 \times 10^{5} \mathrm{~m}^{3}$ of material was eroded from the debris dam, depositing $2.0 \times 10^{5} \mathrm{~m}^{3}$ of material in the channel of the North Fork Toutle River (Meier and others, 1981; Jennings and others, 1981).

Although data are scarce at the present time, it seems that landslide and volcanic dams consisting of pyroclastic debris, if they are going to fail, fail during filling more quickly than other types of landslide or volcanic dams (Michael Church, written communication, 1985). This may be related to unique density, packing, composition, or texture of pyroclastic sediments in natural dams. Obviously this is an important area for further investigation.

Landslide dams are different from constructed fill dams in several important aspects. Landslide dams are a heterogenous mixture of rock and soil whose permeability can vary greatly. Commonly landslide sediments will plug the valley and flow or slide for some distance down-valley. Landslide dams are typically much wider than constructed dams. For example, the South Nation River landslide dam in Canada was $2.5 \mathrm{~km}$ wide (Eden and others, 1971). A transverse section of the Mayunmarca landslide dam in Peru is compared with the Oroville Dam, a large earthfill dam in California in figure 12. The landslide dam is higher at the abutments and almost as high as the constructed dam in the center, but over three times as wide. Landslide dams typically involve large volumes of sediment. The Madison Canyon landslide that dammed the Madison River forming Earthquake Lake in 1959, had a base width five to eight times as great as would have been used in building a rock-fill dam of the same height (Knight and Bennett, 1960).

When a landslide dam is overtopped, there is commonly much more sediment and debris for water to erode before a full breach is developed. This is probably why flood peaks from failed landslide dams appear to be smaller than constructed dam failures with the same dam height and reservoir volume (figs. 4,5; table 6).

Regression equations have been devleoped to predict peak discharge from the landslide dam failure data in table 6. Knowing the height of the 


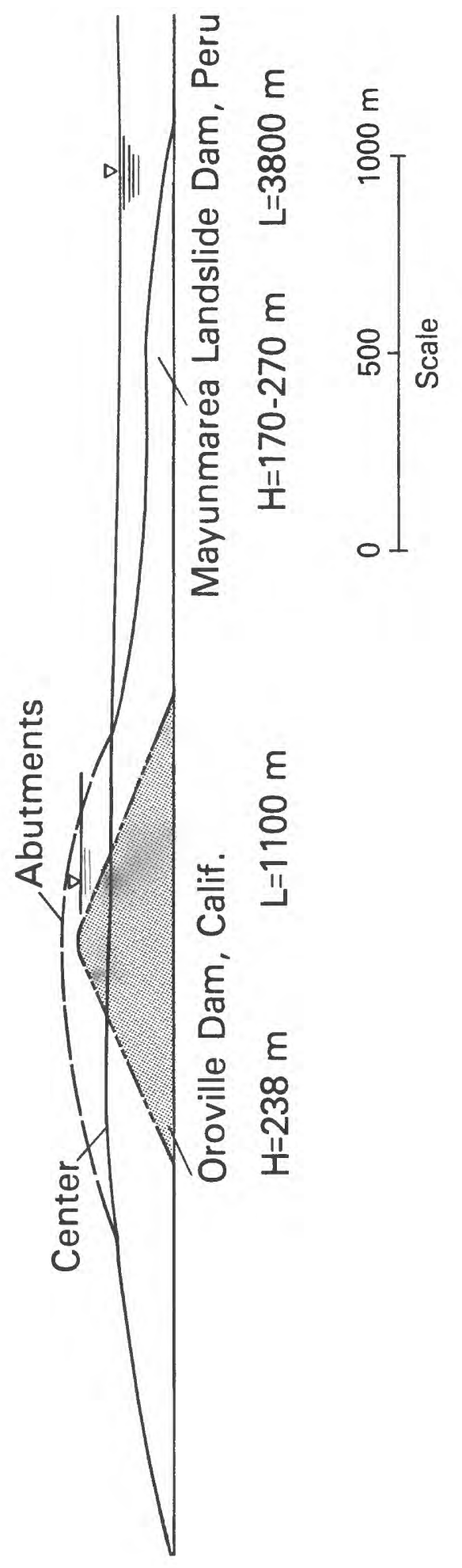

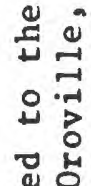

唯

O

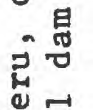

ค.

星出

$\checkmark$ in

ชู

- $\rightarrow 10$

क o :

멍

雨先

娄出

का

豆

艺 㟧

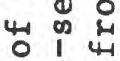

도

- 1 언.

บ 0 .

क 붕 눙

is 昷 4

엃

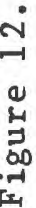

$\underset{2}{3}$ 


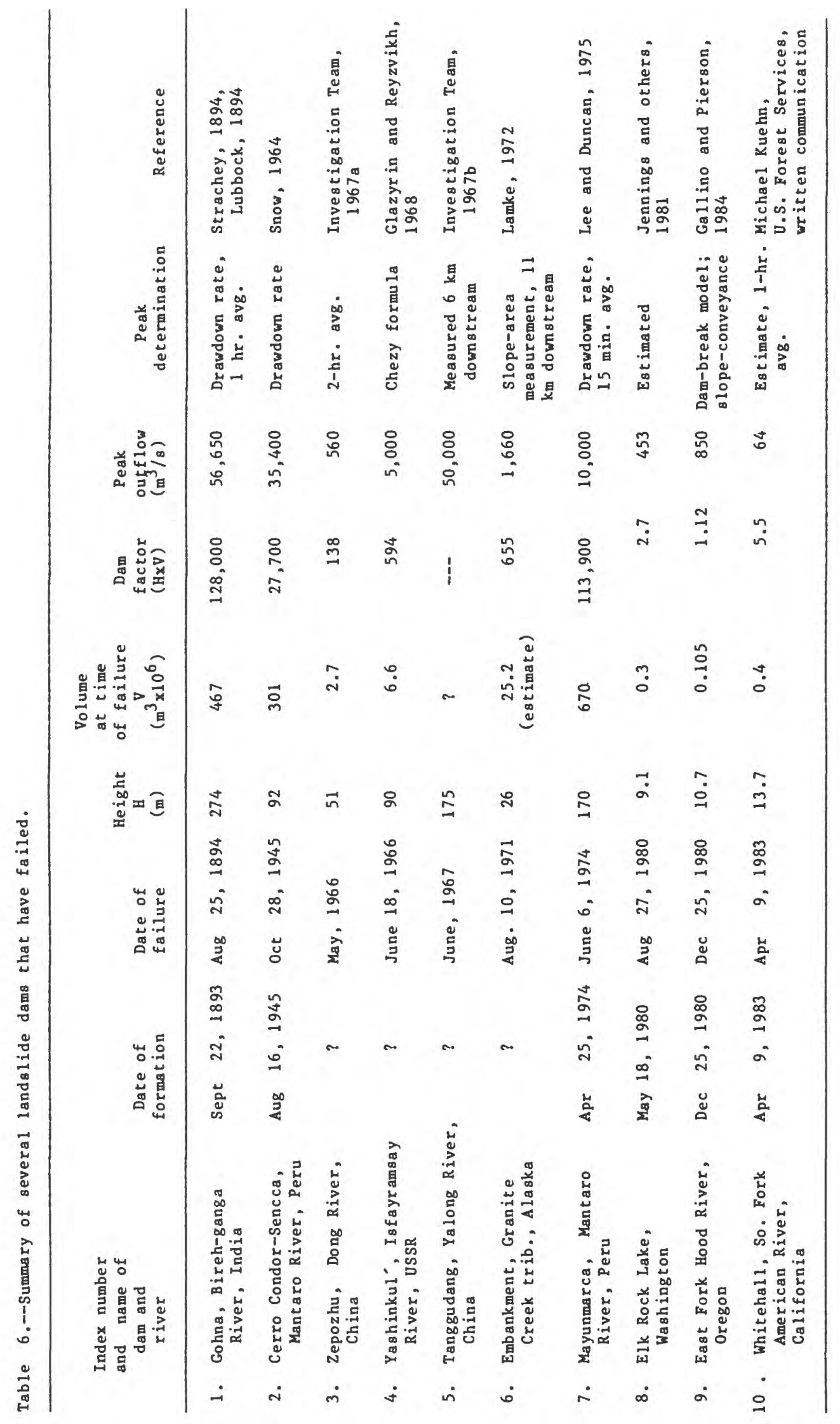


dam in meters:

$$
Q_{\max }=6.3 \mathrm{H}^{1.59} ; \mathrm{r}^{2}=0.74 ; \mathrm{SE}=147 \text { percent; }
$$

knowing the volume $(v)$ at time of failure, in $\mathrm{m}^{3} \times 10^{6}$ :

$$
Q_{\max }=672 \mathrm{v}^{0.56} ; \mathrm{r}^{2}=0.73 ; \mathrm{SE}=142 \text { percent; }
$$

and finally, using the dam factor ( $\mathrm{H} \times \mathrm{V}$ ):

$$
Q_{\max }=181(\mathrm{HV})^{0.43} ; \mathrm{r}^{2}=0.76 ; \mathrm{SE}=129 \text { percent. }
$$

These curves are plotted in figures 4, 5, and 7 .

Hydrographs resulting from landslide dam failures depend on the rate of breach erosion and reservoir characteristics. A hydrograph for the 1974 Mayunmarca landslide dam failure in Peru is shown in figure 13.

The reasons some landslide dams fail and others do not are uncertain. Water seepage through some debris dams obviously maintains lake levels at safe depths and volumes (Adams, 1981). A large percentage of coarse boulders in a debris dam can retard or prohibit erosion if overtopping occurs, and can form a natural riprapped spillway channel, with particles too coarse to move, through which the lake can drain.

Swanson and others (1985) proposed that larger dams blocking smaller rivers will have a smaller probability of failure than a smaller landslide dam below a larger drainage area. In a plot of watershed area versus landslide volume for nine sites in Japan, failed landslide dams clearly cluster as a separate population of smaller landslide volumes in larger drainage areas. With more data, a discriminant function between stable and failed landslide dams may be possible to ascertain, which would allow prediction of the potential for a catastrophic failure.

Today most landslide dams are viewed as serious flood threats, and extraordinary engineering feats are used to remove the dam or control the reservoir levels. In China, a large landslide dammed the Bailong River in 1981. Three hundred metric tons of dynamite were used to blast through the landslide ( $\mathrm{Li}$ and $\mathrm{Hu}, 1982$ ). In the Soviet Union, a large landslide dammed the Zeravshan River north of Afghanistan. The ancient city of Samarkand lay directly in the flood path should the dam fail. A spillway was blasted through the landslide before the lake reached its full capacity of $490 \times 10^{6} \mathrm{~m}^{3}$ (Anonymous, 1964). Another landslide dam formed in the previous year in Yugoslavia near the Bulgarian border. An evacuated village was already submerged in 30 meters of backwater when an emergency spillway was blasted and dug into the landslide dam (Anonymous, 1963).

In the United States, one of the best-known landslide dams that was modified before it overtopped or failed was the dam created by the 1959 Madison Canyon landslide of August 17, 1959, near Yellowstone National Park in Wyoming. An emergency spillway $75 \mathrm{~m}$ wide and $0.8 \mathrm{~km}$ long, and designed to pass a discharge of $280 \mathrm{~m} / \mathrm{s}$, was quickly bulldozed into the landslide 


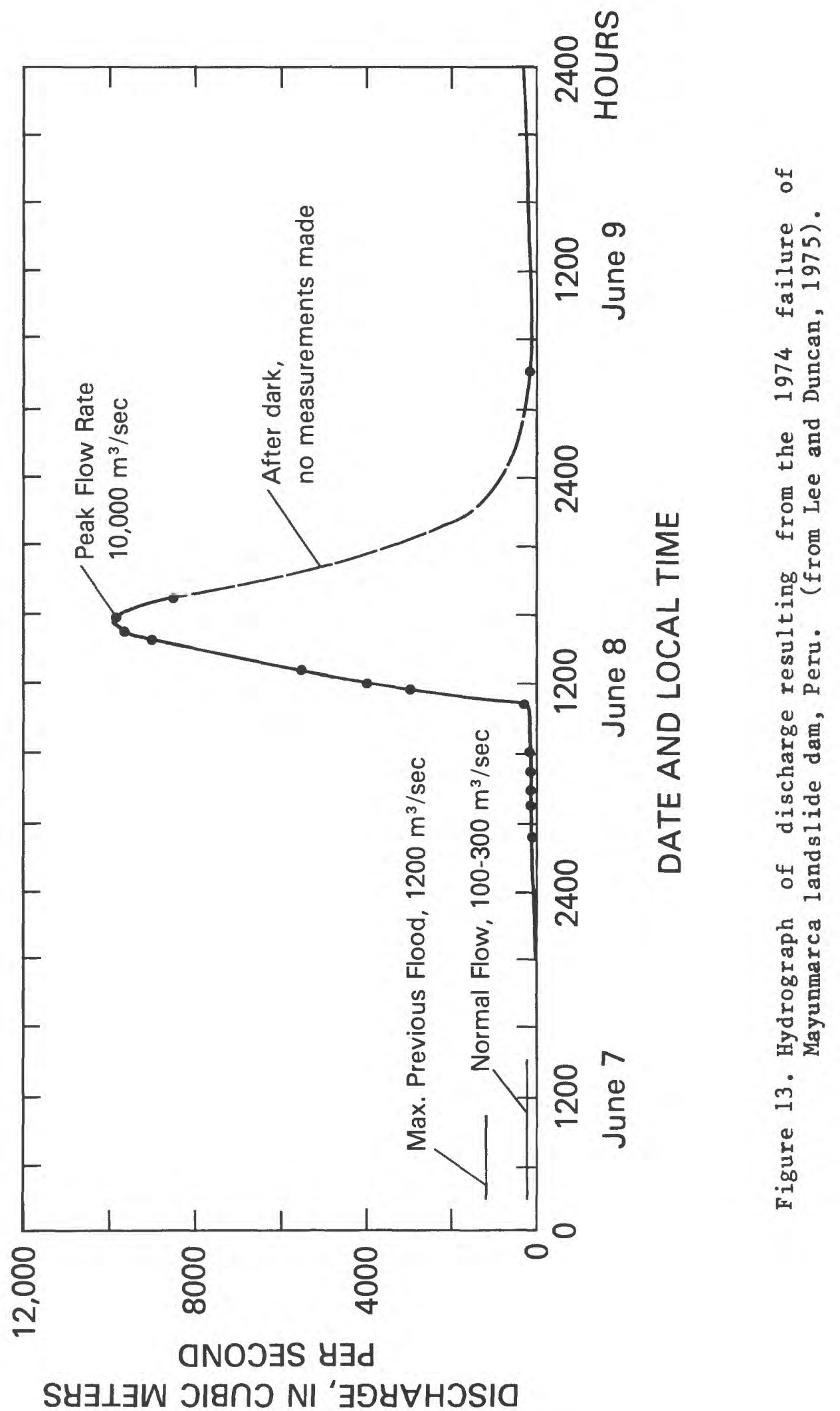


dam, and prevented a potentially catastrophic failure (Stermitz, 1964). More recently, in April 1983 a landslide at Thistle, Utah, dammed the Spanish Fork River and flooded the town, a major transcontinental railroad line, and two highways. The 98 million $\mathrm{m}^{3}$ lake that formed was eventually drained by drilling large tunnels into the right bedrock abutment (Schuster, 1985).

Landslides also may produce floods by the rapid displacement of water in existing lakes and reservoirs. One of the most infamous examples is the Vaiont, Italy Dam failure, the worst dam disaster in history (Kiersch, 1964). On October 9,1963 , over $240 \times 10^{6} \mathrm{~m}^{3}$ of rock and soil $1.8 \mathrm{~km} \mathrm{long}$ and $1.6 \mathrm{~km}$ wide slid rapidly into the reservoir, displacing the water and sending 100-meter-high waves over the top of the dam. About 2,600 people lost their lives in the subsequent flooding downstream. The thin arch concrete dam sustained little damage to its main shell or abutments.

A more recent example of this type of landslide flood occurred in May 1983 near Reno, Nevada (Watters, 1983). A large mass of rock on a mountain slope in the Sierra Nevada slid rapidly into a small reservoir, that overflowed into a second small reservoir. The combined storage capacity of both bodies of water was estimated to have been 15,000-20,000 $\mathrm{m}^{3}$. Four kilometers downstream the resulting flood killed one person, injured others, and damaged several houses and vehicles.

\section{Other types of dam failures}

Four other unusual types of "dam failures" that resulted in large floods can be mentioned. One was the complete draining of Lake Emma, a natural glacial lake located in the San Juan Mountains above Silverton, Colorado. On June 4, 1978, water breached through a network of tunnels in an abandoned mine beneath the lake, emptying the lake (Carrara and others, 1984).

A second unusual "dam failure" occurred on September 29, 1982 in the Sierra Nevada Mountains at Lost Canyon, about $80 \mathrm{~km}$ northeast of Fresno, California. A major public utility company was conducting pre-operational testing of a $6.7 \mathrm{~m}$ diameter water pipeline when the 1 ine ruptured and released a $1,133 \mathrm{~m}^{3} / \mathrm{s}$ flood down Lost Canyon. This flow was sustained for about 1 hour, and was five times the estimated probable maximum flood peak for the drainage basin (Pacific Gas and Electric Company, 1983). The stream channel was scoured, steepened, and straightened, and about 1.34 million $\mathrm{m}^{3}$ of sediment was removed from the canyon.

The third unusual type of "dam failure" occurs in areas of thick peat deposits underlain by impermeable tills. During intense rainstorms, water flows at the peat-till interface and may form large, irregular-shaped mounds of water up to 4 meters high under the peat. These mounds of water will eventually fail, causing what are known as "bog-bursts" in Ireland, Scotland, and England (Colhoun and others, 1965), releasing large floods that can cause great damage. 
The fourth unusual "dam failure" worth noting was the great Boston molasses flood of January 15, 1919. At the inner harbor a distilling company's giant tank, over 15 meters tall and 86 meters in diameter, was filled with 900 cubic meters of molasses. Suddenly the tank burst, and 15,000 metric tons of molasses swept down nearby city streets as a thick brown wave five meters high and moving at 16 meters per second. Twentyone people lost their lives (Hartley, 1981; Lane, 1965), (figure 14).

\section{CHANNEL AND VALLEY CHANGES}

The sudden release of water and sediment as a consequence of the failure of a constructed or natural dam can result in significant changes in the downstream valley and river channel. Such flows can fill valleys and overtop floodplains by 3 to 10 meters or more. The amount of geomorphic change is controlled by the duration of the flood and the slope of the channel. If the duration of high discharge is great, profound geomorphic changes can occur. But if flood peaks are of short duration, and channel slopes sma11, channel changes will be minimal, as in the flat glacial lake floor of Horseshoe Park, Colorado after the Lawn Lake Dam failure in Rocky Mountain National Park (Jarrett and Costa, 1985). Schumm (1969) presents some empirical data on stream channel response to changes in water and sediment loads. Chen and Simons (1979) attempt to apply some of these data to flume studies of simulated dam failures.

The following general characteristics have been reported following large floods from dam failures: (1) Aggradation of the valley upstream by trapped sediment. The sudden and rapid erosion of this stored sediment can have a great impact on the flood-flow hydraulics following dam breaching (Chen and Simons, 1979). In Buffalo Creek, West Virginia, an estimated 153,000 cubic meters of coal waste were deposited in the Buffalo Creek Valley downstream of the dam (Davies and others, 1972); (2) Additional landslides may be triggered by the rapid drawdown of ponded water when the dam is breached (Costa and Baker, 1981, p. 266-267); (3) Down valley, large amounts of local scour and deposition can occur. In the Knik River valley in Alaska, following a jokulhlaup, $2.4 \mathrm{~m}$ of 1 ocal scour and $1.2 \mathrm{~m}$ of local fill were measured (Post and Mayo, 1971). Following the Lawn Lake Dam failure in Rocky Mountain National Park, Colorado, alternating reaches of scour and deposition were observed and measured along a 6-km reach of the Roaring River which has an average slope of 10 percent. Channel reaches steeper than 7-9 percent were extensively scoured, while less steep reaches were depositional sites. As much as 15 meters of scour were measured (Jarrett and Costa, 1985). The same pattern was reported from a dam failure on a steep valley in Great Britain in 1925 (Fearnsides and Wilcockson, 1928).

Following the Teton Dam failure in 1976 in Idaho, the flood waters eroded about one meter of weathered volcanic rocks in the channel, destroyed all trees and vegetation, and stripped topsoil along an 8-km reach of canyon below the dam (fig. 15) (Ray and Kjelstrom, 1978). During the Buffalo Creek, West Virginia dam-break flood, sandstone bedrock along valley walls was eroded (Davies and others, 1972). 


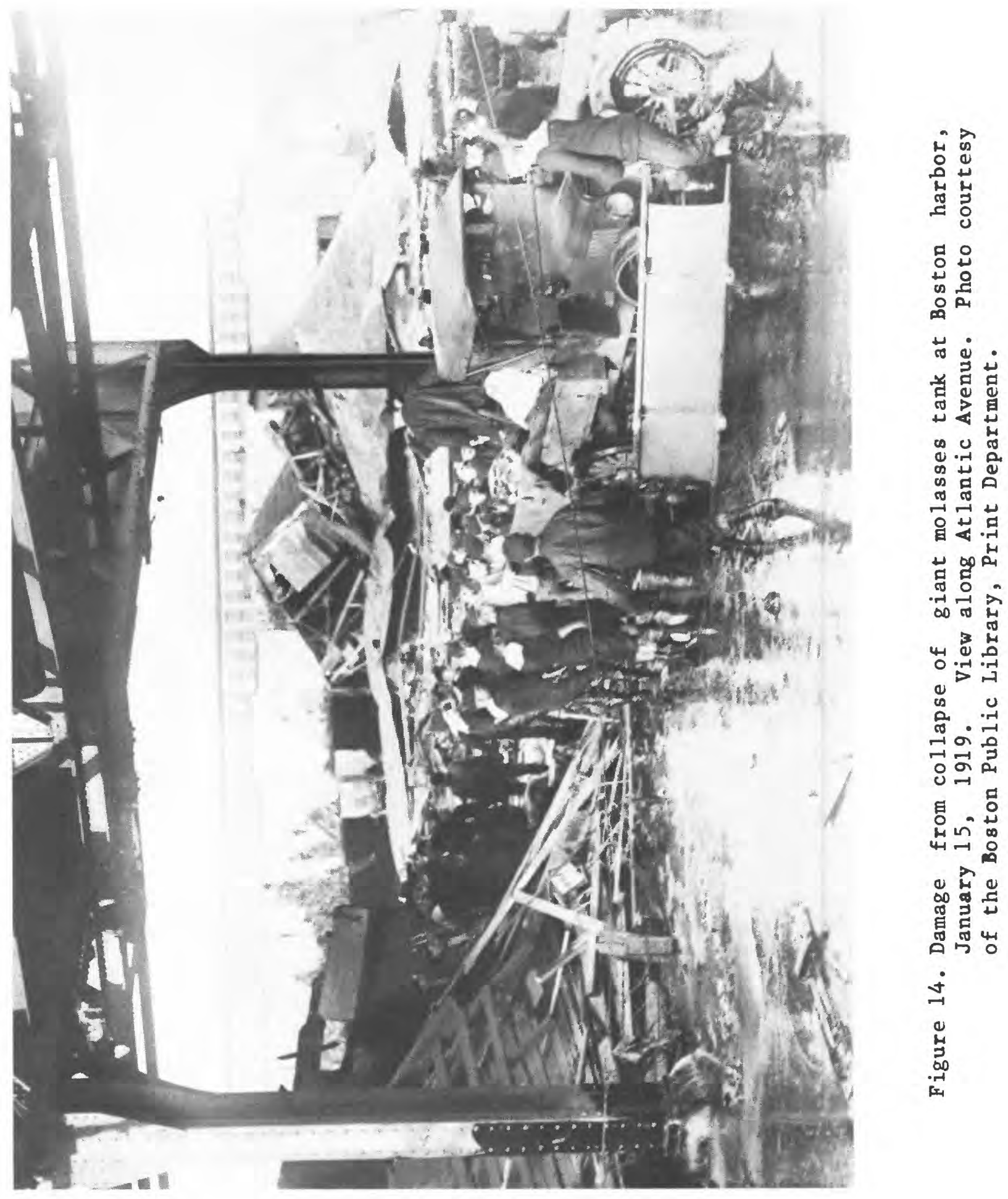


If a landslide dam fails, the large amount of sediment from the dam available for transport can result in wide-spread valley aggradation. The Madison River, Montana, aggraded to an average depth of over 9 meters in 2 months following the Madison Canyon landslide and spillway construction (Hanly, 1964). Following the failure of a large landslide dam in Peru, Snow (1964) documented rapid channel aggradation for many kilometers downstream. As these flood sediments became incised by later flows, terraces formed in the valley. These terraces consisted of poorly sorted, unstratified angular fragments of landslide debris. Upstream of the dam, incision formed terraces in sediments deposited in the ponded water. These terraces contained wel1-sorted, rounded, imbricated, and stratified stream gravels.

Sediments scoured from local surficial deposits during a dam failure can form distinctive depositional features. In Rocky Mountain National Park, Colorado, the Lawn Lake Dam failure flood scoured local moraines and formed an alluvial fan of $0.17 \mathrm{~km}^{2}$ (Jarrett and Costa, 1985). In an investigation of the potential floods accompanying the hypothetical breaching of two large debris dams formed in pyroclastic sediments from the 1980 eruption of Mount St. Helens, Dunne and Fairchild (1983) assumed that the release of a large volume of water onto loose, unconsolidated volcanic deposits would result in rapid erosion and bulking of the floodwaters. They modeled flood peaks assuming sediment concentrations of 300,000 to $1,180,000 \mathrm{mg} / 1$.

Augmented sediment loads in channels downstream from breached dams require steepened slopes for efficient sediment transport. This results in channels that are wide, shallow, and highly braided, such as that of the Gros Ventre River near Kelly, Wyoming following the failure of a landslidedammed lake in 1927 (Alden, 1928).

\section{CONCLUSIONS}

Some of the largest floods to have occurred on the Earth have resulted from the failure of dams. Both constructed dams and natural dams have failed with the resulting loss of many thousands of lives and millions of dollars in property. Estimation of peak discharges from hypothetical dam failures, and routing of those floods down-valley remains an imprecise art. The diversity of dam types, failure mechanisms, and down-valley sediments and morphology make the prediction of channel changes, scour, and deposition speculative. One point becomes clear, however: the ability to estimate the hydrology, hydraulics, and geomorphology of all types of dam failures is predicated upon our knowledge of historic events and appropriate measurements and observations.

For rapid prediction purposes when loss of life or property is involved, a conservative peak discharge estimate based on envelope curves developed from historic dam failures can be made from knowledge of dam height and volume using equations $3,5,6$, or 9 . If breach dimensions can be estimated, equations 11,12 , or 13 may be used. 


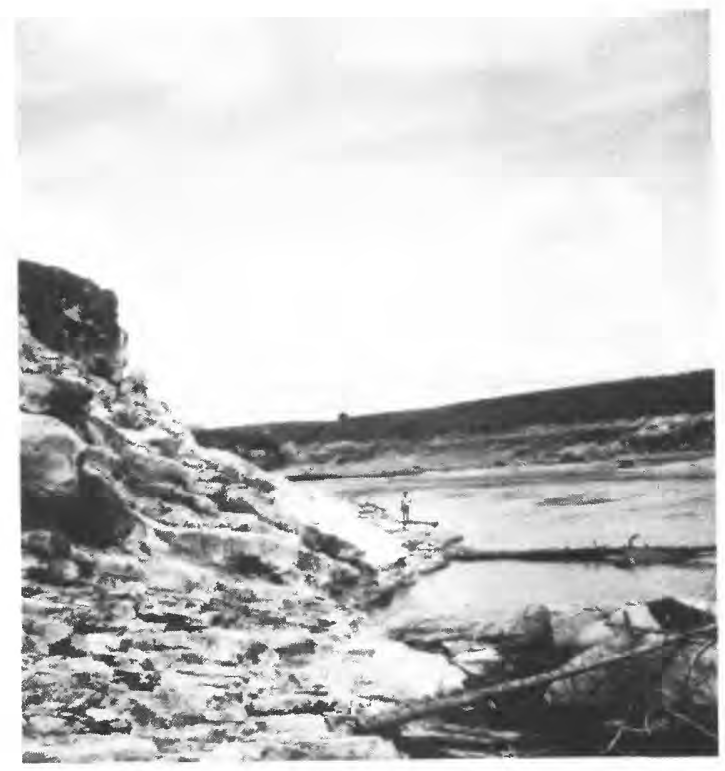

Figure 15. Photograph of Teton River valley at Newdale, Idaho showing area of bedrock erosion along the left bank after the Teton Dam failure in 1976. Person in center of photograph for scale. 
For reconstructing past flood peaks from dam failures for paleohydrological or sedimentological investigations, regression equations with peak discharge as the dependent variable, probably provide a reasonable estimation if dam height and volume of stored water are known. For constructed dams, equation 4 requires knowledge of the dam height to predict peak discharge. For glacial dams and landslide dams, equations 19 and 22 can be used to reconstruct peak discharge.

Regression equations for constructed, landslide, and glacial dams are summarized in table 7. Dam height is the best independent variable to estimate peak discharge for constructed dams. Dam factor (height times volume) is the best independent variable for estimating flood peaks from landslide and glacial dams. For all kinds of dams, dam factor has a lower overall average standard error, and is an approximate measure of the energy expended at the dam at time of failure. Enough we11-documented, intensive investigations of dam failures simply do not exist, especially for landslide dams. These are obvious areas for new and innovative hydrologic and geomorphic research, and the returns will have many practical as well as scientific merits. 


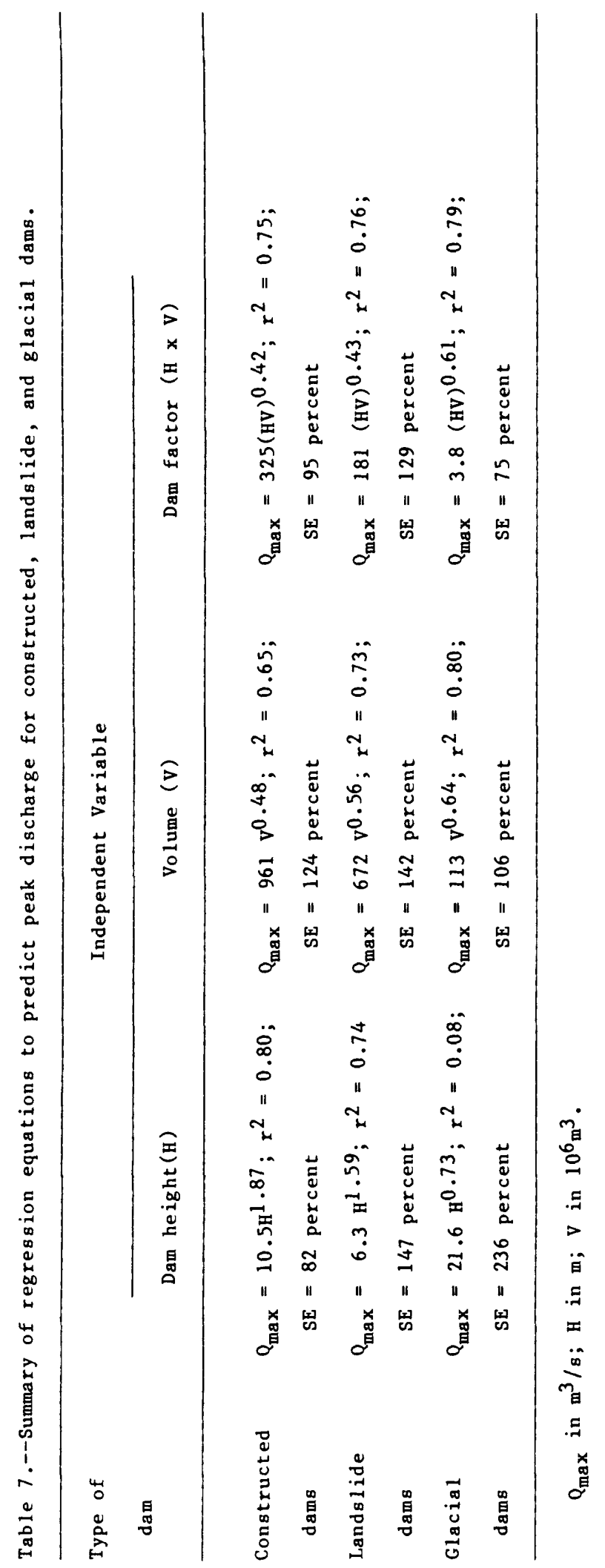




\section{Acknowledgments}

I would like to thank Robert L. Schuster, David C. Froehlich, Robert D. Jarrett, and Julie M. Stewart, U.S. Geological Survey, and Michael Church, University of British Columbia, for excellent constructive reviews of this report.

\section{REFERENCES CITED}

Adams, John, 1981, Earthquake-dammed lakes in New Zealand: Geology, v. 9, p. 215-219.

Aitkenhead, N., 1960, Observations on the drainage of a glacier-dammed lake in Norway: Journal of Glaciology, v. 3, p. 607-609.

Alden, W. C., 1928, Landslide and flood at Gros Ventre, Wyoming: American Institute of Mining and Metallurgical Engineers Transactions, v. 76, p. 347-358.

Anonymous, 1923, Failure of Apishapa earth dam in southern Colorado - II: Eng ineering News-Record, Sept. 13, p. 418-424.

Anonymous, 1925, Undermining causes failure of French Landing Dam: Engineering News-Record, April 30, p. 735-736

Anonymous, 1963, Engineers fear dam won't hold: Engineering News-Record, Apri1 11, p. 22.

Anonymous, 1964, Russians blast through landslide dam: Engineering NewsRecord, May 7, p. 24.

Anonymous, 1969 , Wyoming dam fails: Engineering News-Record, July 17, p. 16 .

Aramaki, Shigeo, 1981, The sequence and nature of 1783 eruption of Asama volcano: in 1981 IAVCEI Symposium, Arc Volcanism, Tokyo and Hakone, Abstracts: Tokyo, Volcanology Society of Japan and International Association of Volcanology and Chemistry of the Earth's Interior, p. 11-12.

Baecher, G. B., Pate, M. E., and de Neufville, Richard, 1980, Risk of dam failure in benefit-cost analysis: Water Resources Research, v. 16, p. 449-456.

Baker, V. R., 1973, Paleohydrology and sedimentology of Lake Missoula flooding in eastern Washington: Geological Society of American Special Paper 144, 79 p.

Barrows, H. K., 1948, Floods, their hydrology and control: New York, McGraw-Hill Book Co., 432 p.

Biswas, A. K., and Chatterjee, Semar, 1971, Dam disasters--An assessment: Engineering Journal (Canada), v. 54, no. 3, p. 3-8.

Blachut, S. P. and Ballantyne, C. K., 1976, Ice-dammed lakes--A critical review of their nature and behaviour: Hamilton, Ontario, McMaster University Department of Geography Discussion Paper No. 6, 90 p.

Blown, Iain, and Church, Michael, 1985, Catastrophic lake drainage within the Homathko River basin, British Columbia: Canadian Geotechnical Journal, v. 22, no. 4, (in press).

Boner, F. C., and Stermitz, Frank, 1967, Floods of June 1964 in northwestern Montana: U.S. Geological Survey Water-Supply Paper $1840-\mathrm{B}, 242 \mathrm{p}$. 
Brater, E. F., and King, H. W., 1976, Handbook of hydraulics: New York, McGraw-Hill Book Co.

Brua, S. A., 1978, Floods of July 19-20, 1977 in the Johnstown area, western Pennsylvania: U.S. Geological Survey Open-File Report 78-963, 62 p.

Carrara, P. E., Mode, W. N., Rubin, Meyer, and Robinson, S. W., 1984, Deglaciation and postglacial timberline in the San Juan Mountains, Colorado: Quaternary Research, v. 21, p. 42-55.

Chen, Y. H., and Simons, D. B., 1979, An experimental study of hydraulic and geomorphic changes in an alluvial channel induced by failure of a dam: Water Resources Research, v. 15, p. 1183-1188.

Clague, J. J., and Mathews, W. H., 1973, The magnitude of jokulhlaups: Journal of Glaciology, v. 12, p. 501-504.

Clarke, G. K. C., 1982 , Glacier outburst floods from "Hazard Lake", Yukon Territory, and the problem of flood magnitude prediction: Journal of Glaciology, v. 28 , p. 3-21.

Colhoun, E. A., Common, R., and Cruickshank, M. M., 1965, Recent bog flows and debris slides in the north of Ireland: Scientific Proceedings of the Royal Dublin Society, series A, v. 2, no. 10, p. 163-174.

Committee on the Safety of Existing Dams, 1983, Safety of existing dams, evaluation and improvement: Washington, D. C., National Academy Press, 354 p.

Costa, J. E. and Baker, V. R., 1981, Surficial Geology: Building with the earth: New York, John Wiley and Sons, Inc., 498 p.

Cotton, C. A., 1944, Volcanoes as landscape forms: Christchurch and London, Whitcombe and Tombs, $416 \mathrm{p}$.

Davies, W. E., Bailey, J. F., and Kelly, D. B., 1972, West Virginia's Buffalo Creek flood--A study of the hydrology and engineering geology: U.S. Geological Survey Circular 667, 32 p.

Dunne, Thomas, and Fairchild, L. H., 1983, Estimation of flood and sedimentation hazards around Mt. St. Helens: Shin-Sabo (Journal of Japanese Erosion Control Society) v. 36, p. 12-22.

Eden, W. J., Fletcher, E. B., and Mitchell, R. J., 1971, South Nation River landslide, 16 May 1971: Canadian Geotechnical Journal, v. 8, p. 446451 .

Eisbacher, G. H. and Clague, J. J., 1984, Destructive mass movements in high mountains--Hazard and management: Geological Survey of Canada Paper 84-16, 230 p.

Fearnsides, W. G., and Wilcockson, W. H., 1928, A topographical study of the flood-swept course of the Porth Llwyd above Dolgarrog: Geographical Journal, v. 72,. p. 401-419.

Field, J. E., 1933, Data on Castlewood Dam failure and flood: Engineering News-Record, Sept. 7, p. 279-280.

Finch, R. H., 1937, A tree-ring calendar for dating volcanic events, Cinder Cove, Lassen National Park, California: American Journal of Science, v. 33, p. 140-146.

Follansbee, Robert, and Jones, E. E., 1922, The Arkansas River flood of June 3-5, 1921: U.S. Geological Survey Water Supply Paper 487, 44 p.

Fread, D. L., 1980, DAMBRK--The NWS dam-break flood forecasting model: Silver Spring, Maryland, National Weather Service, Office of Hydrology, Maryland, 37 p. 
Freeman, G.L., and A1sop, R. B., 1941, Underpinning Austin Dam: Eng ineering News-Record, January 30, 1941 , p. 52-57.

Gallino, G. L., and Pierson, T. C., 1984, The 1980 Polallie Creek debris flow and subsequent dam-break flood, East Fork Hood River basin, Oregon: U.S. Geological Survey Open-File Report 84-578, 37 p.

Glazyrin, G. Ye., and Reyzvikh, V. N., 1968, Computation of the flow hydrograph for the breach of landslide lakes: Soviet Hydrology, no. 5, p. 592-496.

Graham, W. J., 1980, Value of inundation maps in dam failure emergencies: Denver, Colorado, U.S. Bureau of Reclamation, unpublished report, $12 \mathrm{p}$.

Graham, W. J., 1983, Dam failure warning effectiveness: Denver, Colorado, U.S. Bureau of Reclamation, unpublished report, 5 p.

Gruner, Edward, 1963 , Dam disasters: Proceedings, Institution of Civil Engineers, London, v. 24, p. 47-60.

Gunn, J. P., 1930, The Shyok flood, 1929: The Himalayan Journal, v. 2, p., 35-47.

Haeberli, Wilfried, 1983, Frequency and characteristics of glacier floods in the Swiss Alps: Annals of Glaciology, v. 4, p. 85-90.

Hagen, V. K., 1982, Re-evaluation of design floods and dam safety: paper presented at $14 \mathrm{th}$ International Commission on Large Dams Congress, Rio de Janeiro.

Hanly, T. F., 1964, Sediment studies on the Madison River after the Hebgen Lake earthquake: U.S. Geological Survey Professional Paper 435-M, p. 151-158.

Hartley, J. A., 1981 , Boston's great molasses flood: Modern Maturity, v. 24, no. 4, p. 16-18.

Hewitt, Kenneth, 1982, Natural dams and outburst floods of the Karakoram Himalaya, in Glen, J. W., ed., Hydrological aspects of alpine and high-mountain areas: International Association of Hydrological Sciences Publication 138, p. 259-269.

Hildreth, Wes, 1983, The compositionally zoned eruption of 1912 in the Valley of Ten Thousand Smokes, Katmai National Park, Alaska: Journal of Volcanology and Geothermal Research, v. 18, p. 1-56.

Hutchinson, G. E., 1957, A treatise on 1imnology; vo1. 1: New York, John Wiley \& Sons, $1015 \mathrm{p}$.

International Commission on Large Dams, 1973, Lessons from dam incidents: Boston, Massachusetts, Abridged edition, U.S. Commission on Large Dams.

Investigation Team of the Zepozhu Landslide-dammed River, 1967a, Investigation Report of the Zepozhu landslide-dammed lake, Dong River, Xichang County, Sichuan Province, unpublished report, 18 p. (in Chinese).

Investigation Team of the Tanggudang Lands1ide Dam, 1967b, An investigation report on the Landslide dam of Tanggudang on the Yalong River, unpublished report, Chinese Science Committee, Chengdu, 34 p. (in Chinese).

Jansen, R. B., 1980, Dams and public safety: Denver, Colorado, U.S. Department of the Interior, Bureau of Reclamation, Denver, Colorado, $332 \mathrm{p}$. 
Jarrett, R. D. and Costa, J. E., 1985, Hydrology, geomorphology, and dambreak modeling of the July 15, 1982 Lawn Lake Dam and Cascade Lake Dam failures, Larimer County, Colorado: U.S. Geological Survey Open-File Report 84-612, 109 p.

Jennings, M. E., Schneider, V. R., and Smith, P. E., 1981, Computer assessments of potential flood hazards from breaching of two debris dams, Toutle River and Cowlitz River systems, in Lipman, P. W. and Mullineaux, D. R., eds., The 1980 eruption of Mount St. Helens, Washington, U.S. Geological Survey Professional Paper 1250, p. 829836 .

Jessup, W. E., 1964, Baldwin Hills Dam failure: Civil Engineering, v. 34, p. 60-62.

Johnson, F. A., and Illes, P., 1976, A classification of dam failures: International Water Power and Dam Construction, Dec., p. 43-45.

Keefer, D. K., 1984, Landslides caused by earthquakes: Geological Society of America Bu1letin, v. 95, p. 406-421.

Kiersch, G. A., 1964, The Vaiont River disaster: Civil Engineering, v. 34, p. 32-39.

Kirkpatrick, G. W., 1977, Evaluation guidelines for spillway adequacy, in The Evaluation of Dam Safety, .Engineering Foundation Conference, Pacific Grove, California, Proceedings: New York, American Society of Civil Engineers, p. 395-414.

Knight, D. K., and Bennett, P.T., 1960, Stability of slide dam and recommendations on development of overflow spillway: in Report on Flood Emergency, Madison River Slide, Appendix VI: Riverdale, North Dakota, U.S. Army Corps of Engineers, 5 p.

Lamke, R. D., 1972 , Floods of the summer of 1971 in south-central Alaska: U.S. Geological Survey Open-File Report, 88 p.

Land, L. F., 1980a, Evaluation of selected dam-break floodwave models by using field data: U.S. Geological Survey Water-Resources Investigations $80-44,54 \mathrm{p}$.

Land, L. F., 1980b, Mathematical simulations of the Toccoa Falls, Georgia, dam-break flood: Water Resources Bulletin, v. 16, p. 1041-1048.

Lane, F. W., 1965, The elements rage: Philadelphia and New York, Chilton Books, p. 165.

Lee, K. L., and Duncan, J.M., 1975, Landslide of April 25, 1974 on the Mantaro River, Peru: Washington, D.C., National Academy of Sciences, 72 p.

Li Gong-Shou and Hu Tis-Fu, 1982, The activity and taming of Zhouqu landslide-earthflow, in Landslides and Mudflows, Reports of Alma-Ata International Seminar, Centre of International Projects, GKNT, Moscow, p. 466-470.

Lliboutry, Louis, Arnao, B. M., Pautre, Andre, and Schneider, Bernard, 1977, Glaciological problems set by the control of dangerous lakes in Cordillera Blanca, Peru. I. Historical failures of morainic dams, their causes and prevention: Journal of Glaciology, v. 18, p. 239-254. Lubbock, Guy, 1894, The Gohna Lake: Geographical Journa1, v. 4, p. 457.

MacDona1d, T. C., and Langridge-Monopolis, Jennifer, 1984, Breaching characteristics of dam failures: Journal of Hydraulic Engineering, v. 110 , no. 5, p. 567-586. 
Mark, R.K., and Stuart-Alexander, D. E., 1977, Disasters as a necessary part of benefit-cost analyses: Science, v. 197, p. 1160-1162.

Mason, Kenneth, 1929, Indus floods and Shyok glaciers: Himalayan Journal, v. 1, p. 10-29.

Mathews, W. H., 1965, Two self-dumping ice-dammed lakes in British Columbia: Geographical Review, v. 55, p. 46-52.

Mathews, W. H., 1973, Record of two jokulhlaups: International Association of Scientific Hydrology Publication 95, p. 99-110.

McMahon, G. F., 1981, Developing dam-break flood zone ordinance: American Society of Civil Engineers, Journal of the Water Resources Division, v. 107, no. WR 2, p. 461-476.

Meier, M. F., Carpenter, P. J., and Janda, R. J., 1981 , Hydrologic effects of Mount St. Helen's 1980 eruption: EOS, v. 62, p. 625-626.

Morrison, R. E., 1982 , United States dams-statistical data: Association of Engineering Geologists Newsletter, v. 25, p. 19-21.

Nairn, I. A., Wood, C. P., and Hewson, C. A. Y., 1979, Phreatic eruptions of Ruapehu--April 1975: New Zealand Journal of Geology and Geophysics, v. 22, p. 155-173.

Nash, D. F. T., Brunsden, D. K., Hughes, R. E., Jones, D. K. C., and Whalley, B. F., 1985, A catastrophic debris flow near Gupis, northern areas, Pakistan: International Conference on Soil Mechanics and Foundation Engineering, llth, San Francisco, 1985, Proceedings, $4 \mathrm{p}$.

Nye, J. F., 1976, Water flow in glaciers--Jokulhlaups, tunnels, and veins: Journal of Glaciology, v. 17, p. 181-207.

Office of the State Engineer, 1913-1914, Ninth biennial report of State Engineer: Salt Lake City, Utah, $343 \mathrm{p}$.

Outland, C. F., 1977, Man-made disaster--The story of St. Francis Dam: Glendale, California, Arthur H. Clark Co., 275 p.

Pacific Gas and Electric Company, 1983, Description of the environment affected by the Lost Canyon pipe failure: San Francisco, 108 p.

Petrascheck, A. W., and Sydler, P. A., 1984, Routing of dam break floods: International Water Power and Dam Construction, v. 36, p. 29-32.

Post, Austin, and Mayo, L. R., 1971, Glacier dammed lakes and outburst floods in Alaska: U.S. Geological Survey Hydrologic Investigations At las $\mathrm{HA}-455,10 \mathrm{p}$.

Price, J. T., Lowe, G. W., and Garrison, J. M., 1977, Unsteady flow modeling of dam-break waves, in Dam-Break Flood Routing Model Workshop, Bethesda, Maryland, 1977, Proceedings: U.S. Water Resources Council, Hydrology Committee, available only from National Technical Information Service, Springfield, Virginia, $P B-275-437$.

Ray, H. A., and Kjelstrom, L. C., 1978, The flood in southeastern Idaho from the Teton Dam failure of June 5, 1976: U.S. Geological Survey Open-File Report 77-765, 48 p.

Ritter, A., 1892, Die fortpflanzung der wasserwellen: Zeitschrift des Vereines Deutscher Ingenieure, v. 36, no. 33, p. 947-954.

Rose, Don, 1978, Risk of catastrophic failure of major dams: American Society of Civil Engineers, Journal of the Hydraulics Division, v. 104, no. HY9, p. 1349-1351.

Rostvedt, J. 0., and others, 1968, Summary of floods in the United States during 1963: U.S. Geological Survey Water Supply Paper 1830-B, p. B84-B86. 
Sager, J. W., Griffiths, J. B., and Fargo, N. J., 1984, Spirit Lake outlet tunne1: National Research Council, Tunneling Technology Newsletter, no. 48, p. $1-5$.

Sanders, C. L., and Sauer, V. B., 1979, Kelly Barnes Dam flood of November 6, 1977, near Toccoa, Georgia: U.S. Geological Survey Hydrologic Investigations Atlas HA-613, 2 sheets.

Schumm, S. A., 1969, River metamorphosis: American Society of Civil Engineers, Journal of the Hydraulics Division, v. 95, no. HY 1, p. 255-273.

Schuster, R. L., 1984, Effects of landslides and mudflows associated with the May 1980 eruption of Mount St. Helens, northwestern U.S.A.: Journal of Japan Landslide Society, v. 21, p. 1-10.

Schuster, R. L., 1985, Landslide dams in the western United States: International Conference and Field Workshop on Landslides, IV, Tokyo 1985, Proceed ings, 8 p.

Scott, K. M., and Gravlee, G.C., Jr., 1968, Flood surge on the Rubicon River, California--Hydrology, hydraulics, and boulder transport:

U.S. Geological Survey Professional Paper 422-M, 40 p.

Scott, K. M., and Janda, R. J., 1982, Preliminary map of 1 ahar inundation during the Pine Creek eruptive period in the Toutle-Cowlitz River system, Mount St. Helens, Washington: U.S. Geological Survey WaterResources Investigations Report 82-4067.

Silva, L., Cocheme, J. J., Canul, R., Duffield, W. A., and Tilling, R. I., 1982, E1 Chichon volcano: Washington, D. C., Scientific Event Alert Network (SEAN) Bulletin, v. 7 , no. 5, p. 2-6.

Snow, D. T., 1964, Landslide of Cerro Condor-Sencea, Department of Ayacucho, Peru, in G. A. Kiersch, ed., Engineering Geology Case Histories No. 5: Geological Society of America, p. 1-6.

Soil Conservation Service, 1981, Simplified dam-breach routing procedure: U. S. Department of Agriculture, Technical Release 66, Washington, D.C., 25 p. plus appendix.

Stermitz, Frank, 1964, Effects of the Hebgen Lake earthquake on surface water: U.S. Geological Survey Professional Paper 435-L, p. 139-150.

Stone, K. H., 1963, The annual emptying of Lake George, Alaska: Arctic, v. $16, p \cdot 26-40$.

Strachey, R., 1894 , The lands1ip at Gohna, in British Garwhal: Geographical Journal, v. 4, p. 162-170.

Swanson, F. J., Graham, R. L., and Grant, G. E., 1985, Some effects of slope movements on river channels, in International Symposium on Erosion, Debris flow, and Disaster Prevention, Tsukuba, 1985, Proceedings: Tsukuba, Japan,Erosion Control Engineering Society of Japan, $6 \mathrm{p}$.

Swift, C. H., and Kresch, D. L., 1983, Mudflow hazards along the Toutle and Cowlitz Rivers from a hypothetical failure of Spirit Lake blockage: U.S. Geological Survey Water-Resources Investigations Report 82-4125, $10 \mathrm{p}$.

Thorarinsson, Sigurdur, 1953, Some new aspects of the Grimsvotn problem: Journal of Glaciology, v. 2, p. 267-275.

Thorarinsson, Sigurdur, 1957, The jokulhlaup from the Kat 1 a area in 1955 compared with other jokulhlaups in Iceland: Reykjavik, Museum of Natural History Miscellaneous Papers No., 18, p. 21-25. 
Tufuel1, Lance, 1984, Glacier hazards: London, Longman, $97 \mathrm{p}$.

U.S. Bureau of Reclamation, 1982, Ertan hydroelectric project: Denver, Report of U.S. Bureau of Reclamation Team visit to Peoples Republic of China.

Watters, R. J., 1983, A landslide induced waterflood-debris flow: Bulletin of the International Association of Engineering Geology, v. 28, p. 177-182.

Wetmore, J. N., and Fread, D. L., 1981, The NWS simplified dam-break flood forecasting model: Canadian Hydrotechnical Conference, $5 \mathrm{th}$, Fredericton, Canada, 1981, Proceedings, 24 p.

Young, G. J., 1980, Monitoring glacier outburst floods: Nordic Hydrology, v. 11, p. 285-300.

Zen, M. T. and Hadikusumo, D., 1965, The future danger of Mount Kelut (eastern Java-Indonesia): Bulletin of Volcanologie, v. 28, p. 275282 . 